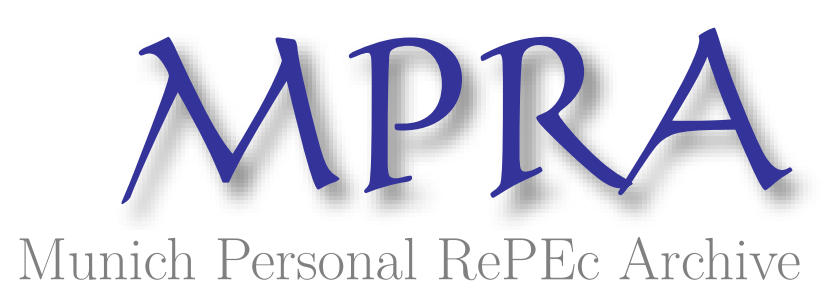

\title{
Border Effects in European Public Procurement
}

Herz, Benedikt and Varela-Irimia, Xosé-Luís

European Commission, European Commission

10 November 2016

Online at https://mpra.ub.uni-muenchen.de/76401/

MPRA Paper No. 76401, posted 30 Jan 2017 10:49 UTC 


\title{
Border Effects in European Public Procurement
}

\author{
Benedikt Herz $^{\alpha}$ and Xosé-Luís Varela-Irimia ${ }^{\beta}$
}

January 2017

First version: November 2016

Preliminary and incomplete.

\begin{abstract}
This paper documents border effects in public procurement in the European Union Single Market. We use a data set of 2.3 million European public procurement contracts awarded between 2010 and 2014 to estimate a gravity model of bilateral procurement flows between European NUTS3 region pairs. Controlling for numerous variables, we find border effects on both the intra- and international level. Cross-national border effects are especially sizable: firms located in the home region of the tendering authority are about 1300 times more likely to be awarded a contract than foreign firms. Our results hold for goods, services, and construction works procurement and cannot be explained by common currency, same language, and variables capturing cultural distance.
\end{abstract}

JEL Classification: H57, F14, F15

Keywords: public procurement, public contract, border effect, home bias, cross-border, gravity model, European Union, Single Market

Disclaimer: The information and views set out in this paper are those of the authors and do not necessarily reflect the official opinion of the European Union. Neither the European Union institutions and bodies nor any person acting on their behalf may be held responsible for the use which may be made of the information contained therein.

The obligatory copyright note: We certify that we have the right to deposit the contribution with MPRA

${ }^{\alpha, \beta}$ Chief Economist Team, Directorate General for Internal Market, Industry, Entrepreneurship and SMEs, European Commission, 1040 Brussels, Belgium. Corresponding author: Benedikt Herz, benedikt.herz@ec.europa.eu. We would like to thank Arleta Wlodarczyk for very helpful comments and suggestions. 


\section{Introduction}

A classic finding in the empirical international trade literature is the existence of a dampening effect of national borders on the volume of trade. One explanation for this "border effect" is the existence of a home-bias, understood as the tendency to award contracts to domestic firms compared to foreign competitors. ${ }^{1}$ Since home bias works similarly to a tariff that distorts competition, ${ }^{2}$ it is likely to have a very detrimental effect on welfare.

In most industrialized countries public procurement accounts for a substantial share of GDP. ${ }^{3}$ The liberalisation of procurement practices, in particular, with the aim of increasing crossborder procurement, has therefore been on the agenda of policy makers for a long time. ${ }^{4}$ Despite this, studies that empirically document and quantify the effect of borders on public procurement outcomes are scarce.

In this paper we fill this gap in the literature by documenting and quantifying border effects in public procurement in the European Single Market. Our empirical analysis is based on 2.3 million European public procurement contracts awarded from 2010 to 2014 and published in the EU's Tenders Electronic Daily database (TED). We match geo-locations to the address information in the data and then assign NUTS3 regions to tenderers and winning bidders to create a data set that consists of 1,362 $\times 1,362$ bilateral public procurement flows between NUTS3 region pairs. Following the seminal work of McCallum (1995), we then use this data set to estimate a gravity model of bilateral procurement flows with border effects. ${ }^{5}$

Despite accounting for NUTS3 origin and destination fixed effects, geographic and cultural distance, and common currency and language, we document evidence of very substantial intra- and international border effects in European public procurement. In our baseline specification, we find for example that a local firm - a firm located in the same NUTS3 region as the tendering authority -- is about twice as likely to win a contract compared to a firm located in the same NUTS2, but in a different NUTS3. We document the most sizable effect for cross-national border effects: a local firm is about 1300 times more likely to be awarded a contract compared to a foreign firm. Our results hold for goods, services, and construction procurement and for different types of public procurement procedures and award criteria. We also show that cultural differences across countries, to the degree to which they can be quantitatively captured, can only explain a relatively small part of the border effect.

The extent of the border effects we find is surprising since formal trade barriers have been abolished in the European Single Market by 1968. At least since the mid-1980s the EU also increasingly abolished non-tariff barriers, such as differences in standards or technical regulations that are imposed by national governments for health and safety reasons.

\footnotetext{
${ }^{1}$ Home bias has also been documented in many other contexts such as, for example, asset holdings (French and Poterba, 1991; Lewis, 1999; Ahearne et al., 2004), the wind turbine industry (Coşar et al., 2015), online products markets (Hortaçsu et al., 2009), online crowdfunding markets (Lin and Viswanathan, 2015).

${ }^{2}$ See, for example, Mattoo (1996) and Trionfetti (2000) for a discussion on the welfare effects in the case of discriminatory public procurement.

${ }^{3}$ For example, the estimate of total general government public procurement expenditure, excluding utilities and defence, was 1931.5 billion euros in 2014, or about 13\% of EU GDP (Public Procurement Indicators 2014, European Commission, February 2, 2016).

${ }^{4}$ Early efforts to bring government procurement under internationally agreed trade rules were undertaken in the OECD framework. The matter was then brought into the Tokyo Round of Trade Negotiations within GATT in 1976. The revised GPA entered into force on 6 April 2014. More recently, tackling the barriers to cross-border procurement has been identified as a policy priority in a Commission Staff Working Document (accessible at http://eur-lex.europa.eu/legal-content/EN/TXT/?uri=CELEX\%3A52015SC0202).

${ }^{5}$ See Head and Mayer (2014) for a review on the border effect and the gravity equation in international trade.
} 
Moreover, there have been substantial efforts to also reduce informal barriers, for example, by standardizing various elements of public procurement procedures ${ }^{6}$ and by moving towards procurement digitalisation. Our findings suggest that barriers of substantial magnitude to cross-border procurement remain. Although there are several other potential explanations for the sizable border effects we document, our results are indicative of home bias in European public procurement.

The remainder of this paper is structured as follows. We relate our paper to the relevant existing literature in the next section. In Section 3 we discuss the data that we use in this article. In Section 4 we present our estimation strategy. We discuss results in Section 5. In the final section we summarize, discuss policy implications, and point out potential avenues for future research.

\section{Related Literature}

This paper is related to a strand of literature that documents the negative impact of borders on the volume of trade using the gravity equation. McCallum (1995) initiated this literature by showing that the US-Canadian border had an unexpectedly strong effect: controlling for numerous variables, trade between the Canadian provinces was about 22 times higher than their trade with US states. ${ }^{7}$

An obvious explanation for the home bias in trade is that formal or informal national barriers to trade such as tariffs, quotas, or regulatory differences must be responsible for this finding. More recently, however, it became clear that there must be additional reasons because sizable border effects were also found to exist in the supposedly highly integrated EU single market (Nitsch, 2000; Chen, 2004), on the subnational in the US (Wolf, 2000, Hillberry and Hummels, 2003, Coughlin and Novy, 2013, Crafts and Klein, 2015), and even on the zipcode level (Hillberry and Hummels, 2008). Crafts and Klein (2015) find that agglomeration effects explain at least part of the home bias in trade. Consequently, they might also explain a part of the home bias we document here for public procurement, however, the sheer size of the home bias we document makes clear that discrimination still seems to be at work.

This paper is also related to a literature that empirically documents some evidence of home bias in public procurement based on descriptive statistics. A study carried out for the European Commission reports that in the European Union only 1.6\% of contracts awarded under the rules of the EU procurement Directives (or $3.5 \%$ of their value) were won by nondomestic bidders. ${ }^{89}$ Using Eurostat input-output data, the same study concluded that import

\footnotetext{
${ }^{6}$ Examples are the standardization of procurement-specific nomenclature by creating the Common Procurement Vocabulary (CPV) and the introduction of standard forms for publication.

${ }^{7}$ We refer the reader to Head and Mayer (2014) for more recent estimates of the border effect in trade.

8 "Cross-border procurement above EU thresholds", 2011, by Ramboll Management Consulting and the University of Applied Sciences HTW Chur.

${ }^{9}$ This is defined in the study as "direct" cross-border procurement. Alternatively, they define a broader category of "indirect" cross-border procurement that includes for example, awards won by local subsidiaries of foreign companies and by consortia of foreign and local firms. In our paper we consider only direct cross-border procurement.
} 
penetration differs significantly between the public and private sectors $(7.5 \%$ to $19.1 \%$ respectively), stating that this difference between the public and private sectors is largely due to differences in the kinds of goods, services and works procured (i.e. that the public sector tends to relatively purchase more services, which are usually less tradable than goods). One should therefore not exclude the possibility that the home bias could just stem from a composition effect. We control for that by fitting our model to subsamples of procurement of goods, services and construction works and we find sizeable and significant border effects in all of them.

Similarly, Trionfetti (2000) and Bruehlhart and Trionfetti (2001) show that the import share of private sector purchases is substantially higher than the import share of government purchases and interpret this as home bias in public procurement. The most recent paper in this literature is Shingal (2015) who explores several explanations for the relatively low share of foreign procurement in Switzerland and Japan for the years 1990-2003.

The present paper adds to this literature in several ways. Methodologically, this paper is the first that follows the trade literature and quantifies the home bias by estimating bilateral procurement flows using a gravity equation. This approach has several advantages. Firstly, it allows us to quantify the home bias while controlling for other explanatory variables, in particular geographical distance as well as origin- and destination fixed effects. Secondly, unlike in the existing descriptive literature where home bias is often simply defined as a "relatively" low share of public vs. private import propensity, a formal test of home bias is straightforward in our estimation framework: home bias exists in case of a significant border coefficient in the estimated gravity equation. Thirdly, because of the fine aggregation of our data, we can explore home bias not only across but also within countries.

\section{Data Description}

This study is based on European public procurement contract awards published on the European Union's Tenders Electronic Daily (TED) website. We use the address information of the contracting authority or entity (CAE) and the winning firms in the data to construct a data set that consists of bilateral procurement flows between NUTS3 region pairs. This data set is then used to estimate a gravity equation with border effects.

\subsection{Institutional Background and Tenders Electronic Daily}

TED is an online supplement ${ }^{10}$ to the Official Journal of the EU containing the details of public procurement notices published under the coverage of the EU public procurement Directives. ${ }^{11}$ These Directives are relevant for and transposed by the EU member states and Norway, Iceland, and Lichtenstein (altogether the European Economic Area, EEA).

\footnotetext{
${ }^{10}$ The supplement is available online at http://ted.europa.eu/TED/.

${ }^{11}$ Currently the Directive 2014/24/EU of the European Parliament and of the Council of 26 February 2014 on public procurement and repealing Directive 2004/18/EC, the Directive 2014/25/EU of the European Parliament and of the Council of 26 February 2014 on procurement by entities operating in the water, energy, transport and postal services sectors and repealing Directive 2004/17/EC, the Directive 2014/23/EU of the European
} 
TED contains information about different types of procurement notices ${ }^{12}$ that reflect the various administrative stages of the public procurement process followed by the CAEs ${ }^{13}$ subject to the Directives. A "contract notice" announces the call for tenders for the provision of works, goods, or services. From it, firms are able to learn relevant information for their bids, like technical specifications, deadlines, award criteria, and other procedural aspects. Then, the CAE assesses the offers and decides who to award the procurement contract to. It is often the case that the procurement requested in a single contract notice is awarded to several firms. This may happen for instance when the contract notice is structured in different lots for which it is possible to bid separately. A single contract notice can therefore lead to one or more contract awards. ${ }^{14}$ In this paper we use information at the contract award level.

The contract awards contain, amongst others, information regarding

- the name and address of the contracting authority or entity,

- the name and address of the winning firm, ${ }^{15}$

- the value of the tender initially expected by the CAE,

- the final value of the tender,

- the number of bids,

- the date of the award,

- the specific award criterion used in the tender,

- and the Common Procurement Vocabulary (CPV) - a code which serves to identify the type of good, service, or work to be procured.

All contract notices whose value exceeds a certain amount are subject to the public procurement Directives and must be published in TED because they are presumed to be of cross-border interest. These thresholds are set in the Directives and updated every two years. ${ }^{16}$ The thresholds apply to the (expected) total value of the contract notice and not

Parliament and of the Council of 26 February 2014 on the award of concession contracts, and Directive 2009/81/EC on the coordination of procedures for the award of certain works contracts, supply contracts and service contracts by contracting authorities or entities in the fields of defence and security.

${ }^{12}$ A complete list of the different public procurement standard forms can be found in the TED website at http://simap.ted.europa.eu/standard-forms-for-public-procurement.

${ }^{13}$ A contracting authority would be for example a ministry or a city council, whereas a contracting entity would be a publicly owned firm.

${ }^{14}$ Technically, the award decisions stemming from the contract notice are published through one or more "contract award notices." For example, one single contract notice can be followed by just one contract award notice which includes various contract awards. However, it can also be the case that there are several contract award notices, each one including one single contract award. Any combination of these two situations is also possible, depending on the specificities of each procurement process. From a formal point of view, a contract award notice is a standard form, whereas a contract award (or award decision) is a specific section within the standard form for a contract award notice. In any case, the actual complexity and options in the procurement process stablished by the Directives is much richer than the one presented in this stylised example.

${ }^{15}$ The data set only contains information on the winning bidder, but not on the other bidding firms.

${ }^{16}$ The complete list of current thresholds is available at https://ec.europa.eu/growth/single-market/publicprocurement/rules-implementation/thresholds_en. As an illustration, in the context of the general procurement covered by Directive 2014/24/EU (i.e., procurement not related to the defence sector, specific utilities sectors or concessions) the procurement of supplies and services by central government authorities has a threshold of Euro 135,000 , although subsidized services or certain services specifically listed have higher thresholds. Works contracts have a threshold of Euro 5,225,000. 
separately to each of the contract award notices and contract awards that stem from it. It is not unusual that a contract notice of large value translates into many contract awards of smaller values that in some cases are below the corresponding threshold. Even in these cases it is compulsory to publish those lower-value contract awards. In practice, this implies that many of the contract awards that we have in our sample have values below the thresholds of the Directives. Moreover, another reason to observe below-threshold contract awards in our dataset is that publication in TED is perceived as a sign of openness and many CAEs decide to publish in TED on a voluntary basis. Therefore, although the TED data base does not include all public procurement exchanges, it does include the most of it in terms of value.

\subsection{Construction of the Data Set}

We use a subset of the TED data that consists of approximately 2.3 million contract awards published between 2010 and 2014. Based on the address information in the data, we assign the NUTS3 region ${ }^{17}$ of the CAE and the winning firm to each contract award. ${ }^{18}$ We then construct a data set that consists of bilateral procurement flows tendered by CAEs located in NUTS3 region $i$ and awarded to firms located in NUTS3 region $j$. We refer to these as the "origin NUTS3" and the "destination NUTS3," respectively, in the following. We limit our sample to origin and destination regions within the EU plus Norway and Lichtenstein. Since there are such 1,362 NUTS3 regions, the data set has $1,362 \times 1,362=1,855,044$ observations where each observation represents a NUTS3 region pair. We add NUTS3 level information on population figures from Eurostat. ${ }^{19}$

In our empirical analysis we use two variables capturing the extent of procurement flows between pairs of regions. Firstly, we use the variable value $e_{i, j}$ that we define as the total value of projects tendered by CAEs in NUTS3 region $i$ and won by firms located in region $j$. Given that the information on final values of awarded contracts is sometimes missing, we also use the variable projects ${ }_{i, j}$ that is defined as the number of total contracts (i.e. not weighted by their value) published by CAEs located in NUTS3 region $i$ and awarded to firms in region $j$. Moreover, we construct variants of these variables that only contain the value of awarded contracts or the number of projects in goods, services, or construction. Descriptive statistics of the main variables used in this study are presented in Table 1.

\footnotetext{
${ }^{17}$ European NUTS regions are territorial nomenclatures based primarily on the current institutional divisions of the respective country, following national regional classifications of generic nature (as opposed to specific regional classifications such as mining regions or rail traffic regions, for example). The NUTS classification has three levels, with NUTS1 and NUTS2 roughly corresponding to, respectively, regions and provinces within a country (the NUTS0 level). The NUTS3 level corresponds to a less important administrative structure that should have an average population between 150.000 and 800.000 inhabitants. NUTS regions can change over time following the needs of the respective countries. In this paper we have followed the NUTS 2013 classification. The respective shape file can be found at http://ec.europa.eu/eurostat/web/gisco/geodata/reference-data/administrative-units-statistical-units.

${ }^{18}$ There are 239,728 distinct town/postal code combinations in our data. For each of these distinct town/postal code combinations, we obtain the latitude and longitude using the Google Maps API. By combining this data with the Eurostat shape file on NUTS3 regions in Europe, we then assign a NUTS3 region to each CAE and to each winning firm in our dataset.

${ }^{19}$ Note that we ignore public contracts won by countries outside of the EEA since the share is negligible.
} 


\subsection{Descriptive statistics}

Before turning to the estimation of the gravity equation, we report some descriptive statistics. Table 2 provides an overview of cross-region and cross-border procurement. Column (2) of Panel A documents that of all projects that were tendered in one of the 1,362 NUTS3 regions in our sample, $31 \%$ were won by a firm in the same NUTS3 region. $16 \%$ were won by firms located in other NUTS3 regions within the same NUTS2. 50\% $(10.8 \%+39.7 \%)$ came from the rest of the country and, finally, about $1.3 \%$ were awarded to firms located outside of the country, that is, in a different NUTS0. Columns (3) to (8) show that at both the NUTS0 and NUTS3 levels the share of cross-border procurement is highest for goods and smaller for services and construction works. Panel B shows that we obtain very similar results when projects are weighted by their value.

Figure 1 visualizes the share of awards by CAEs located in a NUTS3 region that are awarded to firms located in other countries (a different NUTS0). While in general the share of crossborder procurement in the whole EU is low, the map shows that it is not driven by any specific region or Member State. Scandinavian and Baltic countries have a relatively higher cross-border share. The map also suggests that in (geographically) larger countries, like France or Spain, NUTS3 regions closer to the border show higher rates compared to regions in the interior. This effect is particularly apparent is smaller countries like the Benelux and the central-eastern EU area.

It is important to note that, despite being highly suggestive, the evidence reported in in Figure 1 and Table 2 cannot be unambiguously interpreted as evidence of border effects in public procurement. The fact that only few cross-region and cross-border awards take place might be simply because trade costs increase with distance. This is also in line with the finding that we find stronger border effect in the raw data for construction and services than for goods procurement, since the former are more costly to trade over large distance than the latter.

Figure 2, however, presents more descriptive evidence that the border effects we document are indeed due to a border effects, and not just driven by trade costs. The map in the upper left visualizes the geographic distribution of contracts awarded published by authorities located in the NUTS2 region around Frankfurt am Main (DEA2) (marked in green). It is clearly visible that the probability that firms in a given region win an award is decreasing in the distance to the DEA2 NUTS2. Almost no trade across national borders is visible. However, this might be just due to the distance effect. The upper right panel shows a similar map for contracts published by authorities located the NUTS2 region Cologne (DEA2) which adjacent to Germany's national border with Belgium and the Netherlands and close to the border with Luxembourg. This map now provides very clear evidence that the national border matters greatly for procurement: it is apparent that firms based in German NUTS3 regions of equal distance to Cologne have a much higher probability of being awarded a contract than equivalent firms in the Netherlands, Belgium, or Luxembourg.

Figure 2 shows another example. The two Mediterranean islands Corsica and Sardinia are located next to each other; however, the first is part of France while the second is part of Italy. The contract awards clearly reflect this: in spite of similar distance to Italy and France, 
99.8\% and $99.5 \%$ of contracts published by authorities located in Corsica and Sardinia are awarded to France and Italy, respectively.

In the next section, we present a formal way of quantifying border effects in European public procurement based on the gravity model following the methodology proposed in the seminal paper by McCallum (1995).

\section{Estimation Strategy}

The first approach we use to quantify the border effect in European public procurement is based on the traditional gravity equation. We use the popular gravity model that has widely used in the analysis of international trade and more recently in other fields, such as migration and even innovation policy. ${ }^{20}$

We propose a constant-elasticity model of the form

$$
\text { projects_won }_{i, j}=\exp \left(\boldsymbol{X}_{i, j} \boldsymbol{\beta}\right)+\varepsilon_{i, j}
$$

with projects_won $_{i j} \geq 0, E\left[\varepsilon_{i, j} \mid \boldsymbol{X}_{i, j}\right]=0$, and

$$
\begin{aligned}
& \boldsymbol{X}_{i, j} \boldsymbol{\beta}=\text { projects_total }_{i}+\beta_{1} \ln \text { pop }_{i}+\beta_{2} \ln \text { pop }_{j}+\beta_{3} \ln \text { distance }_{i, j} \\
&+\beta_{4} \text { same_NUTS }_{i, j}+\beta_{5}{\text { same_NUTS } 1_{i, j}+\beta_{6} \text { same_NUTS }_{i, j}}+\beta_{7} \text { same_NUTS }_{i, j}
\end{aligned}
$$

The dependent variable projects_won ${ }_{i j}$ is the number of tenders awarded to firms in NUTS3 region $j$ tendered by CAEs located in NUTS3 region $i$. Since by construction the probability to win a tender from a NUTS3 region that launches more tenders is higher, we use the total projects tendered by CAEs located in region i projects_total $_{i}$ as an offset variable. ${ }^{21}$

We expect tenders awarded by a NUTS3 region to rise proportionally to the economic activity of the origin NUTS3 region and tenders awarded to a NUTS3 region rise proportionally to the size of the destination NUTS3 region. We therefore include logpopulation of region $i$ and $j\left(p o p_{i}\right.$ and $\left.p o p_{j}\right)$ as control variables.

We expect that the distance between two NUTS3 regions ( distance $_{i, j}$ ) and the bilateral procurement flow between these two regions have a negative relationship. Distance both captures the transportation cost due to physical distance, however, some argue that it also proxies transaction and information cost more generally (Portes and Rey, 2005)). As

\footnotetext{
${ }^{20}$ See Section 2.4 in Head and Mayer (2014).

${ }^{21}$ One obtains the same results by using the ratio $\frac{\text { projects_won }_{i, j}}{\text { projects_total }_{i}}$ as the dependent variable and weighting the regression by projects_total . $_{\text {. }}$
} 
proposed by Leamer (1997) and Nitsch (2000), we calculate intra-NUTS3 distances based on land area. ${ }^{22}$

Our main estimates of interest are the coefficients on the dummy-variables same_NUTSX $X_{i, j}$ that capture the border effects we want to estimate. We measure border effects at the NUTS0, i.e., the country-level, the NUTS1, NUTS2, and the NUTS3 level. The dummies take the value 1 when $i$ and $j$ are in the same NUTSX.

A potential problem of specification (1) is that coefficient estimates might be biased due to omitted variable bias. ${ }^{23} \mathrm{We}$ address this problem in our baseline approach by including fixed effects for both the destination and the origin NUTS 3 regions: ${ }^{24}$

$$
\begin{gathered}
\boldsymbol{X}_{i, j} \boldsymbol{\theta}=\text { orig }_{i}+\text { dest }_{j}+\theta_{1} \ln \text { distance }_{i, j}+\theta_{2} \text { same_NUTS }_{i, j}+\theta_{3} \text { same }_{-} N U T S 1_{i, j} \\
+\theta_{4} \text { same_NUTS }_{i, j}+\theta_{5} \text { same_NUTS }_{i, j}
\end{gathered}
$$

The fixed effects orig $_{i}$ and dest $_{j}$ capture unobserved characteristics of the origin NUTS3 and the destination NUTS3. ${ }^{25}$

The heavy concentration of awards to nearby regions described in Table 2 implies that the dependent variables reflecting the export flows between regions contain a large count of zeros and a long right tail in the dependent variables. In order to deal with the many zero values of the dependent variable and to avoid inconsistent estimates in the presence of heteroskedasticity, we follow Silva and Tenreyro (2006) and estimate specifications (1) and (2) by using Poisson (pseudo)-maximum likelihood (PPML) with Eicker-White robust standard errors. $^{26}$

\section{Results}

In this section we present the estimation results of our gravity model and provide various robustness checks. We first show the baseline results using the sample of all contract awards. We then estimate the model separately for goods, services, and construction works procurement. In Section 5.3 we analyze the effect of different procedural details of the

\footnotetext{
${ }^{22}$ We follow Head and Mayer (2000) and calculate the intra-NUTS3 distance as distance di,i $_{i}=\left[\frac{2}{3}\left(\frac{\text { area }_{i}}{\pi}\right)^{0.5}\right]$.

${ }^{23}$ Anderson and van Wincoop (2003) show that the "traditional" gravity equation leads to biased estimates due to neglected exporter- and importer-specific multilateral resistance variables. One way of theory-consistent estimation of the gravity equation is to use importer and exporter fixed effects (e.g., Feenstra, 2015, Redding and Venables, 2004, and Section 3.3 in Head and Mayer, 2014).

${ }^{24}$ The estimation of a gravity equation with import and exporter fixed effects is standard in the trade literature in order to account for (unobserved) multilateral resistance terms (Anderson and van Wincoop, 2003). See, for example, Harrigan (1996), Hilberry and Hummels (2003), Coughlin and Novy (2013), and Section 3.3 in Head and Mayer (2014).

${ }^{25}$ Note that since the model is purely cross-sectional, the variables pop $_{i}$, pop $_{j}$, and projects_total $_{j}$ are not part of this extended model because they are captured by the origin and destination fixed effects.

${ }^{26}$ Our data is clearly "over-dispersed", that is, the variance exceeds the mean. As advised by Head and Mayer (2014), we do not follow the recommendation by De Benedictis and Taglioni (2011) to use a negative binomial estimator in this case. Firstly, the PPML estimator remains consistent under over-dispersion. Secondly, as pointed out by Boulhol and Bosquet (2013), amongst other drawbacks, estimates based negative binomial model depend on the units of measurement of the dependent variable.
} 
procurement process. Finally, we document to what extent cultural differences can explain the border effects.

\subsection{Main Results}

Columns (1) to (3) of Table 3 report PPML estimates of regression equations (1) and (2) when the number of projects projects $s_{i j}$ is the dependent variable. Column (1) shows results of the traditional gravity equation. Column (2) reports estimates of the extended gravity equation that includes fixed effects for the NUTS3 region of origin and destination. Our baseline specification in column (3) then adds dummy-variables for common language and whether the origin and destination NUTS3 region use a common currency (i.e., whether both use the Euro).

In all our specifications we find that distance has a strong negative impact on the likelihood of winning a tender. According to our baseline specification in column (3), when the distance between the contracting authority's NUTS3 region and a given firm's NUTS3 regions doubles, the probability of that firm winning a tender decreases by about $32 \%(\exp (-0.382))$.

We find evidence of substantial border effects at both international and intra-national levels in all three specifications. According to the baseline specification in column (3), firms located in the same NUTS3 as the contracting authority (hereafter "local firms") are two times $(\exp (0.722)=2.06)$ more likely to win a tender than firms located in a different NUTS3 within the same NUTS2 of the contracting authority. Firms located in a different NUTS2, but still within the same NUTS1 than the CAE are 4.6 times $(\exp (0.722+0.813)=4.64)$ less likely to win than a local firm. Firms located in a different NUTS1 than the CAE are 7.25 times $(\exp (0.722+0.813+0.452)=7.257)$ less likely to win compared to local firms. The most substantial border effect is the international one: a local firm is almost 1300 times $(\exp (5.172+0.452+0.813+0.722)=1279.21)$ more likely to win than a foreign firm.

One needs to be careful to not interpret these sizable border effects as trade barriers. As we discuss in more detail below, theory shows that the border effect is identical to the product of the elasticity of substitution between "local" and "non-local" goods, services, and works, and the tariff-equivalent of any border barrier (e.g., Anderson and van Wincoop, 2003). If goods, services, and works provided by "local" and "non-local" firms are very similar and therefore highly substitutable, a minor trade barrier or home bias can result in a very substantial border effect.

Column (3) also shows that having the same language and the same currency increases the likelihood of winning a tender by about $159 \% \quad(\exp (0.954)=2.59)$ and $94 \%$ $(\exp (0.664)=1.94)$, respectively. ${ }^{27}$

Columns (4) and (6) document that results are similar when value $i j$, the total final value of projects, is the dependent variable. Comparing columns (3) and (6), we find that when

\footnotetext{
${ }^{27}$ This finding is in line with Rose and van Wincoop (2001) who quantify the effect of different currencies on barriers to international trade.
} 
weighted in by the total final value of the projects, distance becomes slightly more important. However, border effects altogether become slightly less important and having the same currency is no longer significant. This might be interpreted as evidence that discrimination is slightly smaller for bigger projects.

\subsection{Goods, Services, and Construction Works Procurement}

Apart from goods procurement, services and construction works procurement comprises a large share of projects in our data: Between 2010 and 2014 around 48\% of awards referred to service or works contracts, equaling about $66 \%$ of the value of all awards (Table 2). While the baseline results reported in Table 3 are based on all contract awards in our data set, there are several reasons to expect that the determinants of goods procurement and of services and works procurement might differ, in particular regarding border and distance effects. ${ }^{28}$

Firstly, the provision of works and most services, with the exception of, e.g., electronically delivered business services, requires physical contact between producers and consumers. Works and services are also more likely to be "tailored" to the customer and therefore potentially require monitoring and quality control (e.g., Freund and Weinhold, 2002). Their provision to distant locations is therefore often infeasible or very costly. Secondly, due to the higher requirement for personal interaction and communication, language and cultural issues might be relatively more important for the provision of services and construction than for the provision of goods. Finally, national regulations regarding the provision of services and works are widespread and potentially act as barriers to trade. ${ }^{29}$

Table 4 presents the results of estimating equation (2) using the subsamples of procurement of goods, services and construction works, both in terms of number of projects and of total final value of the projects. We find that distance is a much stronger deterrent of procurement flows for services, especially for construction works, than for goods. More precisely, when the distance between the CAE and the firm doubles, the likelihood of winning a tender for goods decreases by $26 \%$ (exp(-0.305)), whereas it reduces by almost $40 \%(\exp (-0.614))$ in the case of services procurement and by more than $65 \%(\exp (-1.071))$ in the case of construction. These results, based on the number of projects, are also confirmed in the sample weighted by the total final value of the projects (columns (4)-(6)).

Combined border dummy variables play a more important role in the procurement of services than in goods or construction works. For instance, in services a local firm is almost 1900 times $(\exp (4.863+0.721+1.004+0.955))$ more likely to win than a foreign firm, while just 373 times more $(\exp (3.677+0.725+0.725+0.797))$ in the case of works and almost 700

\footnotetext{
${ }^{28}$ This is confirmed in the empirical trade literature. Using a gravity model, Kimura and Lee (2006) and Head et al. (2009) find that services trade is subject to stronger distance effects than goods trade. Similarly, using a structural gravity model, Anderson et al. (2015) find important differences in the determinants of goods and services trade. They document large border effects in services trade that vary widely by sector in an intuitive way. Importantly, they also show that border effect in services trade have been falling in the last years. This is line with the view that the emergence of the internet greatly facilitated the trade of certain services (Freund and Weinhold; 2002, 2004). See also Tharakan et al. (2005) who, using gravity framework, finds no distance effect of Indian software (services) exports.

${ }^{29}$ See, for example, Nordås and Rouzet (2015) and Nordås (2016).
} 
$(\exp (5,688+0,182+0,467+0,206))$ times more in the case of goods. However, intra-national border effects are clearly higher in the case of services and construction works. For example, compared to a national firm located in a different NUTS1 than the CAE, a local firm is 14.6 times $(\exp (0,721+1,004+0,955))$ more likely to win a service contract and 9.5 times $(\exp (0,725+0,725+0,797))$ more likely to win a works contract. In the procurement of goods the local firm will only be $2.3(\exp (0,182+0,467+0,206))$ times more likely to win. These results suggest that within national borders the procurement trade is easier for goods than for services and works. Conversely, the border effects are higher for the procurement of goods. This mixed effect of intra- and international cross border dummies is consistent with the theory of Coughlin and Novy (2016) postulating that countries with larger internal trade frictions tend to have smaller border effects. ${ }^{30}$

We also find support for the hypothesis that services and construction works require relatively more personal interaction and communication and that having the same language is therefore more important. For construction works and services, having the same language increases the likelihood of an award by about $600 \%$ and $200 \%$, respectively, while this figure is only $50 \%$ for goods. ${ }^{31}$

The effect of sharing the same currency is smaller in magnitude and less clear. While the same currency is most important for goods and least important for construction works when the number of projects is the dependent variable, this pattern is reversed when the final value of projects is considered in columns (4) to (6). This implies that while having different currencies might represent barrier to the procurement of relatively low value goods, the importance decreases when value is taken into account. One reason why having the same currency is relatively more important for construction works is potentially that the duration of projects is longer and the contracting parties are therefore more exposed to exchange rate fluctuations. We leave it for future research to explore this issue in more detail.

In summary, while we find important differences between border effect of public procurement of goods, services, and construction works, border effects are sizable for each type of procurement we consider.

\subsection{Procedural Details: Award Criteria and Type of Procedure}

In this section we analyse whether the border effects we document above could be driven by the choice of certain administrative procedures. We analyse the effect of the award criterion used in a tender and whether a tender is published under an "open" or "restricted" procedure.

\subsubsection{Award Criteria}

\footnotetext{
${ }^{30}$ Coughlin and Novy (2016) build a model of symmetric micro regions which are aggregated to form larger regions. Spatial frictions increase the relative cost of intra-national trade such that internal trade frictions are relatively larger for larger countries. As a consequence, the relative cost of cross-border trade becomes relatively smaller. In our econometric model, the subsamples of procurement of goods, services and construction works can be subject to different types of trade frictions, including spatial ones. Following the theory of Coughlin and Novy (2016) we can thus expect that whenever intra-national trade faces higher barriers, the corresponding border effects will be relatively smaller, and the other way round.

${ }^{31}$ Respectively, $\exp (1.950)-1, \exp (1.131)-1$, and $\exp (0.411)-1$.
} 
The public procurement Directives ${ }^{32}$ provide that the CAE shall base the award of public contracts either on the lowest price only or on the so-called "most economically advantageous tender" (MEAT). Under the MEAT criterion, other factors than price (like quality, costeffectiveness, after-sales service, etc.) are taken into account for the award. ${ }^{33}$ In our sample $48 \%$ and $45 \%$ of the contracts have been awarded following the lowest price and MEAT criterion, respectively (Table 2) ${ }^{34}$ From a geographic point of view, lowest price is relatively more popular in Eastern EU member states.

The price-only criterion is directly comparable and in principle less subject to product differentiation effects that can soften competition. Therefore, it could be the case that regions where MEAT is more prevalent show lower rates of cross-border procurement because foreign firms may find it more difficult to bid competitively taking into account factors other than price that can be linked to local preferences or specificities.

Panels A and B in Table 5 present the results for the subsamples of tender using the MEAT and lowest price criterion, respectively. The national border effect captured by same_NUTS0 remains sizable and statistically significant for both subsamples. The intra-national border effects are larger in general in the case of MEAT. In particular, the coefficient of same_NUTS3 is substantially larger in the subsample of MEAT, suggesting that when factors other than price are included in the assessment of tenders the firms located in the same NUTS3 as the CAE increase their chances of winning compared to other firms in the country. In line with this, the negative impact of distance on the likelihood to win is more important in the MEAT subsample (with the exception of construction works, where both are of similar levels). Also, having a common language and currency are also more important determinants in the case of MEAT than lowest price. Overall, there is strong evidence that intra-national trade is subject to higher barriers in the case of MEAT than lowest price. Conversely, the international border effect is relatively higher for the subsample of lowest price, which is line with the theory proposed by Coughlin and Novy (2016), as discussed previously. Qualitatively, the same results hold when the total final value is considered instead of the number of projects.

\subsubsection{Type of Procedure}

The public procurement Directives ${ }^{35}$ establish the general obligation of CAEs to award public contracts by using so called "open" or "restricted" procedures. In an open procedure any interested firm can submit a tender whereas in a restricted procedure any firm can request to participate in the tendering process but only those firms invited by the CAE will be able to submit a tender.

Under specific circumstances other procedures can be used. These are for instance the "negotiated" procedure, which can take place with or without the publication of a previous

\footnotetext{
${ }^{32}$ See Directive 2004/18/EC and Directive 2004/17/EC.

${ }^{33}$ The new Directives 2014/24/EC and 2014/25/EC set, without prejudice to national legislations, MEAT as the preferential award mechanism.

${ }^{34}$ For the remaining awards information on the award criterion used is missing.

${ }^{35}$ See Directive 2004/18/EC and Directive 2004/17/EC.
} 
contract notice, and the "competitive dialogue." In a negotiated procedure the CAE consults the firms of its choice and negotiates the terms of the contract with them. In a competitive dialogue the CAE usually has a specific procurement need, i.e., a need for which a suitable solution is not readily available in the market. Any firm can request to participate in the process, but the CAE can select those with which to discuss the manners to satisfy its need and following those discussions the CAE is allowed to narrow down further the list of firms allowed to submit a tender. ${ }^{36}$

The open and restricted procedures may be regarded as the more competitive ones in nature. They are also the most commonly used: About $90 \%$ of projects (85\% when measured according to value) in our data sets are tendered either according to the "open" or "restricted" procedure (see Table 1).

Table 6 shows the results of estimating equation (2) when only projects that use the "open" or "restricted" procedure are considered. When comparing the results to column (3) and (6) in Table 3 and to the results in Table 4, it is apparent that the results are very similar. The border effects that we document above are therefore not a result of the tendering procedure.

\subsection{Cultural Differences}

In this section we explore to what extent differences in cultural values can explain border effects in public procurement. Recent research has shown that cultural values are an important determinant of economic exchange. In a standard gravity model, Felbermayr and Toubal (2010) and Tadesse and White (2007) find that measures of cultural proximity positively affect trade volumes for Europe and the US, even after controlling for fixed effects and other covariates. Guiso et al. (2009) document that bilateral trust, as a reflection of cultural biases, has an important impact trade, portfolio investments, and FDI between European countries. Other research finds that cultural differences affect interest rates in international syndicated bank loans (Gianetti and Yafeh, 2010), venture-capital flows (Bottazzi et al., 2016), cross-regional migration flows (Falck et al., 2012), and the volume of cross-border mergers (Ahern et al., 2015).

The most well-known approaches to construct measures of cultural values are the European Values Study and the World Values Survey, the five-dimension classification system of Hofstede (1980, 2001), the three- dimension system of Schwartz (1994), the seven-dimension system of Trompenaars and Hampden-Turner (2011), and the four-dimension system of Fiske (1991). Because the importance of trust for economic exchange is well documented, and since measures of "hierarchy" and "individualism" are shared by all of the above classification systems, we follow Ahern et al. (2015) and measure cultural values by using respondents' answers in the 2008 and $2009^{37}$ waves of the European Values Study to three questions capturing the attitude regarding the following aspects:

\footnotetext{
${ }^{36}$ There exists also a variant of the negotiated and restricted procedures called "accelerated," where deadlines are shortened if additional conditions are met.

${ }^{37}$ We use the latest waves available. Belgium, Finland, Italy, Sweden, and Great Britain were surveyed in 2009 , the rest of countries in our sample and Northern Ireland were surveyed in 2008.
} 
1. Trust versus distrust: "Generally speaking, would you say that most people can be trusted or that you can't be too careful in dealing with people?"

2. Hierarchy versus egalitarianism: "People have different ideas about following instruction at work. Some say that one should follow instructions of one's superiors even when one does not fully agree with them. Others say that one should follow one's superior's instructions only when is convinced that they are right. Which of these two opinions do you agree with?"

3. Individualism versus collectivism: "Income equality. How would you place your views on this scale?" (From 1 "Incomes should be made more equal" to 10 "We need larger income differences as incentives").

Table 7 reports results when cultural differences between country $i$ and $j$ are operationalized as $\ln \left(1+\mid \Delta\right.$ trust $\left._{i, j} \mid\right), \ln \left(1+\mid \Delta\right.$ hierarchy $\left._{i, j} \mid\right)$, and $\ln \left(1+\mid \Delta \text { individualism }_{i, j} \mid\right)^{38}$, and are included as control variables in regression equation (2). The bilateral distance between two countries in terms of trust is always highly significant and has a negative impact on the number of cross-border procurement projects. Cultural distance as measured by hierarchy and individualism, on the other hand, is mostly not significantly different from zero. Since our measures of cultural differences only vary across but not within countries, coefficients on the same_NUTS1- same_NUTS3 are virtually not affected by the inclusion of the cultural distance variables. The coefficients of geographical distance, same language and same currency dummies remain also almost unchanged compared to the baseline specification.

When comparing column (1) in Panel A of Table 7 to the baseline results in column (3) of Table 3, it is apparent that the estimated coefficient on the same_NUTS0 dummy is substantially smaller: when controlling for cultural distance, residing in the same country as the CAE (but in a different NUTS1) increases the likelihood of winning 126 fold $(\exp (4.486))$ instead of 175 fold $(\exp (5.172))$. The effect becomes much smaller, however, when projects are weighted by their value (Panel B). Cultural differences therefore seem to work as an implicit international trade barrier, however, only for relatively low-value public procurement.

\section{Conclusions}

In this paper, we use a previously unexploited data set of 2.3 million public contract award decisions to empirically quantify border effects in public procurement in the European Single Market. We construct a data set of bilateral public procurement flows between NUTS3 region pairs and, following a methodology first proposed by McCallum (1995), we estimate a gravity model with border effects. We document very sizable inter- and intra-national border effects despite controlling for numerous variables, such as origin- and destination fixed effects, physical distance, common language and currency and cultural similarity.

\footnotetext{
${ }^{38}$ Note that unlike for example the trust matrix used in Guiso et al. (2009), these measures are symmetric, i.e., the distance from country $i$ to country $j$ is the same as the distance from $j$ to $i$.
} 
In our baseline results we find evidence of both intra- and international border effects. For example, a local firm -- a firm located in the same NUTS3 region as the CAE -- is about twice as likely to win a contract as a non-local firm in the same NUTS2 region and it is about 7 times more likely to be awarded compared to a firm in a different NUTS1 region. We document the most sizable border effects on the international level: a local firm is almost 1300 times more likely to be awarded a contract than a foreign firm. We also document that, in line with the literature on empirical trade, the border effects are weaker for goods procurement and larger for construction works and services procurement. Moreover, we find that the award criterion used has an impact on the border effects: intra-national border effects when are larger the "most economically advantageous tender" instead of the "lowest price" criterion is used. The latter is of some policy importance, because since recently the former is now the preferential award mechanism. Finally, we find that cultural differences across European Member States can only explain a relatively small part of border effects.

It is out of the scope of this paper to disentangle the relative importance of the many possible causal factors behind the border effects we document. Our findings, however, are surprising since customs duties and quantitative restrictions were progressively abolished in the European Single Market by 1968. We can therefore exclude that formal trade barriers are the reason for the border effects we document in this paper. Moreover, above-threshold European public procurement legislation is explicitly aimed at promoting cross-border procurement. In particular, tendering procedures have been harmonized in order to prevent the administrative burden of cross-border transactions. Also, the requirement that all above-threshold contracts must be publicized at the EU-level has been introduced. This implies that information asymmetries, that is, the fact that firms are simply unaware of ongoing tenders in other countries are unlikely to be the reason for the border effects.

At least since the mid-1980s, the EU also focused on abolishing non-tariff barriers, such as differences in standards or technical regulations that are imposed by national governments for health and safety reasons. ${ }^{39}$ Moreover, there have been efforts to reduce "hidden" trade costs, such as the (real or perceived) relative difficulty in enforcing contracts across jurisdictions. ${ }^{40}$ In any case, while remaining non-tariff barriers and "hidden" trade costs between countries might have some importance for national border effects, they cannot explain the substantial within-country border effects that we documented in this paper.

Therefore, while there are other potential explanations of border effects, ${ }^{41}$ our results can be seen as being indicative of some home bias in public procurement. That is, our findings

\footnotetext{
${ }^{39}$ See, for example, the 1985 White Paper COM(85) 310 final "Completing the Internal Market" (Commission of the European Communities, 1985). We refer the reader to Head and Mayer (2000) for an economic evaluation of the "Single European Act" that was implementing some of the issues that were raised. Recent evidence that technical barriers diminish the trade volume of goods can be found in Chen (2004) and Essaji (2008).

${ }^{40}$ For example, Anderson and Marcouiller (2002) show evidence that such "hidden" trade costs might reduce the volume of trade.

${ }^{41}$ For example, in an experimental setting, Roux et al. (2016) find that tacit collusion based on the home-market principle can explain a major part of the observed home bias. Moreover, some of the border effects might be due to differences in national administrative procedures (while still being compliant with EU Directives). The existence of personal linkages or other network effects might also play a role.
} 
suggest that contracting authorities might have a preference for consuming locally provided goods, services, and construction works.

From a policy and welfare perspective an important aspect is the degree of similarity between "local" and "non-local" goods, services, and works. In particular, theory shows that the border effect is identical to the product of the elasticity of substitution between "local" and "nonlocal" goods, services, and works, and the tariff-equivalent of any border barrier (e.g., Anderson and van Wincoop, 2003). If goods, services, and works provided by "local" and "non-local" firms are very similar and therefore highly substitutable, a minor trade barrier or home bias can result in a very substantial border effect. In this case, the consequences for welfare, however, would be minor and scope for policy action would be smaller. If, on the other hand, the substitutability is low and border effects are primarily driven by trade barriers, adverse welfare effects and the need for policy makers to act might be substantial (Evans, 2003).

\section{References}

Ahearne, A. G., W. L. Griever, and F. E. Warnock (2004). Information costs and home bias: An analysis of US holdings of foreign equities. Journal of International Economics 62(2), 313-336.

Ahern, K. R., D. Daminelli, and C. Fracassi (2015). Lost in translation? The effect of cultural values on mergers around the world. Journal of Financial Economics 117(1), 165-189.

Anderson, J. E., I. Borchert, A. Mattoo, and Y. V. Yotov (2015). Dark costs, missing data: Shedding some light on services trade. Working Paper 21546, National Bureau of Economic Research.

Anderson, J. E. and D. Marcouiller (2002). Insecurity and the pattern of trade: An empirical investigation. Review of Economics and Statistics 84(2), 342-352.

Anderson, J. E. and E. van Wincoop (2003). Gravity with gravitas: A solution to the border puzzle. The American Economic Review 93(1), 170-192.

Bottazzi, L., M. Da Rin, and T. Hellmann (2016). The importance of trust for investment: Evidence from venture capital. Review of Financial Studies.

Brülhart, M. and F. Trionfetti (2001). Industrial specialisation and public procurement: Theory and empirical evidence. Journal of Economic Integration, 106-127.

Chen, N. (2004). Intra-national versus international trade in the European Union: Why do national borders matter? Journal of International Economics 63(1), 93-118.

Commission of the European Communities (1985). Completing the internal market. White paper from the Commission to the European Council.

Coşar, A. K., P. L. Grieco, and F. Tintelnot (2015). Borders, geography, and oligopoly: Evidence from the wind turbine industry. Review of Economics and Statistics 97(3), 623637. 
Coughlin, C. C. and D. Novy (2013). Is the international border effect larger than the domestic border effect? Evidence from US trade. CESifo Economic Studies 59(2), 249-276.

Coughlin, C. C. and D. Novy (2016). Estimating border effects: The impact of spatial aggregation. Discussion Paper 11226, CEPR.

Crafts, N. and A. Klein (2014). Geography and intra-national home bias: U.S. domestic trade in 1949 and 2007. Journal of Economic Geography.

De Benedictis, L. and D. Taglioni (2011). The Gravity Model in International Trade, Chapter 4, pp. 55-89. Berlin, Heidelberg: Springer Berlin Heidelberg.

Essaji, A. (2008). Technical regulations and specialization in international trade. Journal of International Economics 76(2), 166-176.

European Commission (2016). Public procurement indicators 2014.

Evans, C. L. (2003). The economic significance of national border effects. The American Economic Review 93(4), 1291-1312.

Falck, O., S. Heblich, A. Lameli, and J. Südekum (2012). Dialects, cultural identity, and economic exchange. Journal of Urban Economics 72(2), 225-239.

Feenstra, R. C. (2015). Advanced international trade: theory and evidence. Princeton University Press.

Felbermayr, G. J. and F. Toubal (2010). Cultural proximity and trade. European Economic Review 54(2), 279-293.

Fiske, A. P. (1991). Structures of social life: The four elementary forms of human relations: Communal sharing, authority ranking, equality matching, market pricing. Free Press.

French, K. R. and J. M. Poterba (1991). Investor diversification and international equity markets. The American Economic Review 81(2), 222-226.

Freund, C. and D.Weinhold (2002). The internet and international trade in services. The American Economic Review 92(2), 236-240.

Freund, C. L. and D.Weinhold (2004). The effect of the internet on international trade. Journal of International Economics 62(1), 171-189.

Giannetti, M. and Y. Yafeh (2012). Do cultural differences between contracting parties matter? Evidence from syndicated bank loans. Management Science 58(2), 365-383.

Guiso, L., P. Sapienza, and L. Zingales (2009). Cultural biases in economic exchange? The Quarterly Journal of Economics, 1095-1131.

Harrigan, J. (1996). Openness to trade in manufactures in the OECD. Journal of International Economics 40(1), 23-39. 
Head, K. and T. Mayer (2000). Non-europe: The magnitude and causes of market fragmentation in the EU. Review of World Economics 136(2), 284-314.

Head, K. and T. Mayer (2014). Chapter 3 - Gravity equations: Workhorse, toolkit, and cookbook. In E. H. Gita Gopinath and K. Rogoff (Eds.), Handbook of International Economics, Volume 4 of Handbook of International Economics, pp. 131-195. Elsevier.

Head, K., T. Mayer, and J. Ries (2009). How remote is the offshoring threat? European Economic Review 53(4), 429-444.

Hillberry, R. and D. Hummels (2003). Intranational home bias: Some explanations. Review of Economics and Statistics 85(4), 1089-1092.

Hillberry, R. and D. Hummels (2008). Trade responses to geographic frictions: A decomposition using micro-data. European Economic Review 52(3), 527-550.

Hofstede, G. (1980). Culture's consequences: International differences in work-related values. Sage, Beverly Hills, CA.

Hofstede, G. (2001). Culture's consequences: Comparing values, behaviors, institutions and organizations across nations. Sage Publications, Thousand Oaks, CA.

Hortaçsu, A., F. A. Martínez-Jerez, and J. Douglas (2009). The geography of trade in online transactions: Evidence from eBay and MercadoLibre. American Economic Journal: Microeconomics 1(1), 53-74.

Kimura, F. and H.-H. Lee (2006). The gravity equation in international trade in services. Review of World Economics 142(1), 92-121.

Leamer, E. E. (1997). Access to western markets, and eastern effort levels. In Lessons from the Economic Transition, pp. 503-526. Springer.

Lewis, K. K. (1999). Trying to explain home bias in equities and consumption. Journal of Economic Literature 37(2), 571-608.

Lin, M. and S. Viswanathan (2015). Home bias in online investments: An empirical study of an online crowdfunding market. Management Science 62(5), 1393-1414.

Mattoo, A. (1996). The government procurement agreement: Implications of economic theory. The World Economy 19(6), 695-720.

McCallum, J. (1995). National borders matter: Canada-US regional trade patterns. The American Economic Review 85(3), 615-623.

Nitsch, V. (2000). National borders and international trade: Evidence from the European Union. Canadian Journal of Economics/Revue Canadienne d'Économique 33(4), 1091-1105.

Nordås, H. K. (2016). Services trade restrictiveness index (STRI): The trade effect of regulatory differences. 
Nordås, H. K. and D. Rouzet (2015). The impact of services trade restrictiveness on trade flows.

Portes, R. and H. Rey (2005). The determinants of cross-border equity flows. Journal of International Economics 65(2), 269-296.

Ramboll Management Consulting and University of Applied Sciences HTW Chur (2011). Cross-border procurement above EU thresholds. Final report, European Commission.

Redding, S. and A. J. Venables (2004). Economic geography and international inequality. Journal of International Economics 62(1), 53-82.

Rose, A. K. and E. van Wincoop (2001). National money as a barrier to international trade: The real case for currency union. The American Economic Review 91(2), 386-390.

Roux, C., L. Santos-Pinto, and C. Thöni (2016). Home bias in multimarket Cournot games. European Economic Review 89, 361-371.

Schwartz, S. H. (1994). Beyond individualism/collectivism: New cultural dimensions of values. In Individualism and collectivism: Theory, method, and applications, pp. 85-119. Sage Publications, Inc.

Shingal, A. (2015). Econometric analyses of home bias in government procurement. Review of International Economics 23(1), 188-219.

Silva, J. S. and S. Tenreyro (2006). The log of gravity. The Review of Economics and Statistics 88(4), 641-658.

Tadesse, B. and R. White (2010). Cultural distance as a determinant of bilateral trade flows: do immigrants counter the effect of cultural differences? Applied Economics Letters 17(2), $147-152$.

Tharakan, P., I. Van Beveren, and T. Van Ourti (2005). Determinants of India's software exports and goods exports. Review of Economics and Statistics 87(4), 776-780.

Trionfetti, F. (2000). Discriminatory public procurement and international trade. The World Economy 23(1), 57-76.

Trompenaars, F. and C. Hampden-Turner (2011). Riding the waves of culture: Understanding diversity in global business. Nicholas Brealey Publishing.

Wolf, H. C. (2000). Intranational home bias in trade. Review of Economics and Statistics $82(4), 555-563$. 
8 Tables and Figures

$\underline{\text { Table 1: Descriptive Statistics }}$

\begin{tabular}{|c|c|c|c|c|}
\hline \multicolumn{5}{|c|}{ Panel A: All Projects } \\
\hline & $(1)$ & $(2)$ & (3) & (4) \\
\hline & mean & $\mathrm{sd}$ & $\min$ & $\max$ \\
\hline Number of Projects & 0.97 & 49.26 & 0.00 & 28388.00 \\
\hline Goods & 0.51 & 31.44 & 0.00 & 18418.00 \\
\hline Services & 0.36 & 18.96 & 0.00 & 11486.00 \\
\hline Construction Works & 0.10 & 6.81 & 0.00 & 4364.00 \\
\hline Total Final Value in Euros & 0.10 & 6.08 & 0.00 & 4054.00 \\
\hline Goods & 0.03 & 2.47 & 0.00 & 1452.00 \\
\hline No Goods & 0.07 & 3.98 & 0.00 & 2637.00 \\
\hline Services & 0.05 & 3.33 & 0.00 & 2576.00 \\
\hline Construction & 0.02 & 1.31 & 0.00 & 776.60 \\
\hline
\end{tabular}

Panel B: Only Projects with "Most economically advantageous tender" award criteria

\begin{tabular}{lcccc}
\hline & $(1)$ & $(2)$ & $(3)$ & $(4)$ \\
\hline & mean & sd & $\min$ & $\max$ \\
Number of Projects & 0.43 & 21.18 & 0.00 & 10579.00 \\
Goods & 0.17 & 8.50 & 0.00 & 7975.00 \\
Services & 0.26 & 14.73 & 0.00 & 8198.00 \\
Construction Works & 0.06 & 5.47 & 0.00 & 3865.00 \\
& & & & 1703.00 \\
Total Final Value in Euros & 0.05 & 2.84 & 0.00 & 455.50 \\
Goods & 0.01 & 0.71 & 0.00 & 1030.00 \\
No Goods & 0.02 & 1.60 & 0.00 & 1062.00 \\
Services & 0.03 & 2.22 & 0.00 & 712.90 \\
Construction & 0.01 & 1.05 & 0.00 & \\
\hline
\end{tabular}

Panel C: Only Projects with "Open and Restricted" Type of Procedure

\begin{tabular}{|c|c|c|c|c|}
\hline & $(1)$ & $(2)$ & (3) & (4) \\
\hline & mean & sd & $\min$ & $\max$ \\
\hline Number of Projects & 0.86 & 44.24 & 0.00 & 26058.00 \\
\hline Goods & 0.48 & 30.65 & 0.00 & 18242.00 \\
\hline Services & 0.38 & 18.89 & 0.00 & 9769.00 \\
\hline Construction Works & 0.09 & 5.79 & 0.00 & 3715.00 \\
\hline Total Final Value in Euros & 0.08 & 4.94 & 0.00 & 3264.00 \\
\hline Goods & 0.03 & 2.28 & 0.00 & 1432.00 \\
\hline Services & 0.05 & 3.09 & 0.00 & 1950.00 \\
\hline Construction & 0.02 & 1.17 & 0.00 & 689.50 \\
\hline \multicolumn{5}{|c|}{ Panel D: Other Variables } \\
\hline & $(1)$ & $(2)$ & (3) & (4) \\
\hline & mean & $\mathrm{sd}$ & $\min$ & $\max$ \\
\hline \multicolumn{5}{|l|}{ Same Region Dummies } \\
\hline same_NUTS0 & 0.13 & 0.33 & 0.00 & 1.00 \\
\hline same_NUTS1 & 0.02 & 0.13 & 0.00 & 1.00 \\
\hline same_NUTS2 & 0.01 & 0.07 & 0.00 & 1.00 \\
\hline same_NUTS3 & 0.00 & 0.03 & 0.00 & 1.00 \\
\hline Distance, in $1000 \mathrm{~km}$ & 1.14 & 0.89 & 0.00 & 13.42 \\
\hline Distance, in $1000 \mathrm{~km}(\log )$ & -0.13 & 0.79 & -6.60 & 2.60 \\
\hline Same Language & 0.14 & 0.35 & 0.00 & 1.00 \\
\hline Same Currency & 0.48 & 0.50 & 0.00 & 1.00 \\
\hline
\end{tabular}

Notes: Descriptive statistics are shown. The number of observations is $1,855,044$. 
Table 2: Cross-border Procurement

\begin{tabular}{|c|c|c|c|c|c|c|c|c|}
\hline & $(1)$ & (2) & (3) & (4) & $(5)$ & $(6)$ & (7) & (8) \\
\hline \multicolumn{9}{|c|}{ All projects } \\
\hline & \multicolumn{2}{|c|}{ All } & \multicolumn{2}{|c|}{ Goods } & \multicolumn{2}{|c|}{ Services } & \multicolumn{2}{|c|}{ Construction Works } \\
\hline & Number & Share & Number & Share & Value & Share & Value & Share \\
\hline Same NUTS3 & 561213 & $31.31 \%$ & 198371 & $21.15 \%$ & 275929 & $41.81 \%$ & 86129 & $44.76 \%$ \\
\hline Same NUTS2 & 300609 & $16.77 \%$ & 127651 & $13.61 \%$ & 132289 & $20.04 \%$ & 40371 & $20.98 \%$ \\
\hline Same NUTS1 & 194707 & $10.86 \%$ & 102175 & $10.89 \%$ & 70808 & $10.73 \%$ & 21481 & $11.16 \%$ \\
\hline Same Country & 712017 & $39.73 \%$ & 494158 & $52.68 \%$ & 174381 & $26.42 \%$ & 42890 & $22.29 \%$ \\
\hline Different Country & 23777 & $1.33 \%$ & 15659 & $1.67 \%$ & 6569 & $1.00 \%$ & 1539 & $0.80 \%$ \\
\hline Total & 1792323 & $100.00 \%$ & 938014 & $100.00 \%$ & 659976 & $100.00 \%$ & 192410 & $100.00 \%$ \\
\hline \multicolumn{9}{|c|}{ Subsample: only Projects with "Most economically advantageous tender" award criteria } \\
\hline & \multicolumn{2}{|c|}{ All } & \multicolumn{2}{|c|}{ Goods } & \multicolumn{2}{|c|}{ Services } & \multicolumn{2}{|c|}{ Construction Works } \\
\hline & Value & Share & Value & Share & Value & Share & Value & Share \\
\hline Same NUTS3 & 274441 & $34.13 \%$ & 70540 & $21.92 \%$ & 145761 & $39.80 \%$ & 57475 & $50.01 \%$ \\
\hline Same NUTS2 & 136608 & $16.99 \%$ & 40774 & $12.67 \%$ & 71324 & $19.48 \%$ & 24377 & $21.21 \%$ \\
\hline Same NUTS1 & 87660 & $10.90 \%$ & 38644 & $12.01 \%$ & 39163 & $10.69 \%$ & 9787 & $8.52 \%$ \\
\hline Same Country & 293998 & $36.56 \%$ & 164918 & $51.25 \%$ & 106182 & $29.00 \%$ & 22563 & $19.63 \%$ \\
\hline Different Country & 11397 & $1.42 \%$ & 6905 & $2.15 \%$ & 3764 & $1.03 \%$ & 722 & $0.63 \%$ \\
\hline Total & 804104 & $100.00 \%$ & 321781 & $100.00 \%$ & 366194 & $100.00 \%$ & 114924 & $100.00 \%$ \\
\hline \multicolumn{9}{|c|}{ Subsample: only Projects with "Lowest price" award criteria } \\
\hline & \multicolumn{2}{|c|}{ All } & \multicolumn{2}{|c|}{ Goods } & \multicolumn{2}{|c|}{ Services } & \multicolumn{2}{|c|}{ Construction Works } \\
\hline & Value & Share & Value & Share & Value & Share & Value & Share \\
\hline Same NUTS3 & 245269 & $28.55 \%$ & 116784 & $21.04 \%$ & 109771 & $44.93 \%$ & 18612 & $31.42 \%$ \\
\hline Same NUTS2 & 143713 & $16.73 \%$ & 78768 & $14.19 \%$ & 52303 & $21.41 \%$ & 12483 & $21.07 \%$ \\
\hline Same NUTS1 & 94937 & $11.05 \%$ & 57347 & $10.33 \%$ & 27151 & $11.11 \%$ & 10265 & $17.33 \%$ \\
\hline Same Country & 364768 & $42.45 \%$ & 294384 & $53.04 \%$ & 52938 & $21.67 \%$ & 17221 & $29.07 \%$ \\
\hline Different Country & 10521 & $1.22 \%$ & 7707 & $1.39 \%$ & 2155 & $0.88 \%$ & 655 & $1.11 \%$ \\
\hline Total & 859208 & $100.00 \%$ & 554990 & $100.00 \%$ & 244318 & $100.00 \%$ & 59236 & $100.00 \%$ \\
\hline
\end{tabular}

\begin{tabular}{|c|c|c|c|c|c|c|c|c|}
\hline & (1) & (2) & (3) & (4) & (5) & (6) & (7) & (8) \\
\hline \multicolumn{9}{|c|}{ All Projects } \\
\hline & \multicolumn{2}{|c|}{ All } & \multicolumn{2}{|c|}{ Goods } & \multicolumn{2}{|c|}{ Services } & \multicolumn{2}{|c|}{ Construction Works } \\
\hline & Value & Share & Value & Share & Value & Share & Value & Share \\
\hline Same NUTS3 & 69116.87 & $37.32 \%$ & 16380.60 & $25.66 \%$ & 36529.76 & $43.36 \%$ & 15932.26 & $43.57 \%$ \\
\hline Same NUTS2 & 32475.32 & $17.54 \%$ & 8420.58 & $13.19 \%$ & 15982.05 & $18.97 \%$ & 8010.77 & $21.91 \%$ \\
\hline Same NUTS1 & 21385.18 & $11.55 \%$ & 7987.69 & $12.51 \%$ & 9229.23 & $10.96 \%$ & 4113.45 & $11.25 \%$ \\
\hline Same Country & 58307.70 & $31.49 \%$ & 28509.37 & $44.66 \%$ & 21398.45 & $25.40 \%$ & 8260.04 & $22.59 \%$ \\
\hline Different Country & 3897.76 & $2.10 \%$ & 2543.57 & $3.98 \%$ & 1101.41 & $1.31 \%$ & 249.48 & $0.68 \%$ \\
\hline Total & 185182.83 & $100.00 \%$ & 63841.81 & $100.00 \%$ & 84240.90 & $100.00 \%$ & 36565.99 & $100.00 \%$ \\
\hline
\end{tabular}

\begin{tabular}{|c|c|c|c|c|c|c|c|c|}
\hline \multirow[b]{2}{*}{ description } & \multicolumn{2}{|c|}{ All } & \multicolumn{2}{|c|}{ Goods } & \multicolumn{2}{|c|}{ Services } & \multicolumn{2}{|c|}{ Construction Works } \\
\hline & Value & Share & Value & Share & Value & Share & Value & Share \\
\hline Same NUTS3 & 34954.45 & $38.70 \%$ & 5707.96 & $22.18 \%$ & 18854.64 & $43.08 \%$ & 10143.09 & $49.65 \%$ \\
\hline Same NUTS2 & 16680.73 & $18.47 \%$ & 3078.97 & $11.96 \%$ & 9019.73 & $20.61 \%$ & 4555.43 & $22.30 \%$ \\
\hline Same NUTS1 & 9143.01 & $10.12 \%$ & 3365.44 & $13.08 \%$ & 4166.69 & $9.52 \%$ & 1595.01 & $7.81 \%$ \\
\hline Same Country & 27961.24 & $30.95 \%$ & 12608.67 & $48.99 \%$ & 11222.12 & $25.64 \%$ & 4029.21 & $19.72 \%$ \\
\hline Different Country & 1589.81 & $1.76 \%$ & 977.88 & $3.80 \%$ & 501.78 & $1.15 \%$ & 107.54 & $0.53 \%$ \\
\hline Total & 90329.24 & $100.00 \%$ & 25738.92 & $100.00 \%$ & 43764.96 & $100.00 \%$ & 20430.29 & $100.00 \%$ \\
\hline \multicolumn{9}{|c|}{ Subsample: only Projects with "Lowest price" award criteria } \\
\hline & \multicolumn{2}{|c|}{ All } & \multicolumn{2}{|c|}{ Goods } & \multicolumn{2}{|c|}{ Services } & \multicolumn{2}{|c|}{ Construction Works } \\
\hline description & Value & Share & Value & Share & Value & Share & Value & Share \\
\hline Same NUTS3 & 29530.71 & $35.47 \%$ & 10007.96 & $28.59 \%$ & 15458.63 & $43.90 \%$ & 4043.25 & $31.36 \%$ \\
\hline Same NUTS2 & 13890.43 & $16.69 \%$ & 4929.47 & $14.08 \%$ & 6093.66 & $17.30 \%$ & 2832.29 & $21.97 \%$ \\
\hline Same NUTS1 & 11278.15 & $13.55 \%$ & 4327.97 & $12.36 \%$ & 4633.47 & $13.16 \%$ & 2278.50 & $17.67 \%$ \\
\hline Same Country & 26458.88 & $31.78 \%$ & 14285.80 & $40.81 \%$ & 8511.08 & $24.17 \%$ & 3624.29 & $28.11 \%$ \\
\hline Different Country & 2091.26 & $2.51 \%$ & 1457.96 & $4.16 \%$ & 519.16 & $1.47 \%$ & 113.45 & $0.88 \%$ \\
\hline Total & 83249.43 & $100.00 \%$ & 35009.15 & $100.00 \%$ & 35216.00 & $100.00 \%$ & 12891.78 & $100.00 \%$ \\
\hline
\end{tabular}

Notes: Panel A documents the number and share of projects that were won by the same NUTS3, NUTS2, NUTS1, and the same country they were tendered by. Panel B shows the some when projects are weighted by the total final value in Euros. 


\section{Table 3: Main Results}

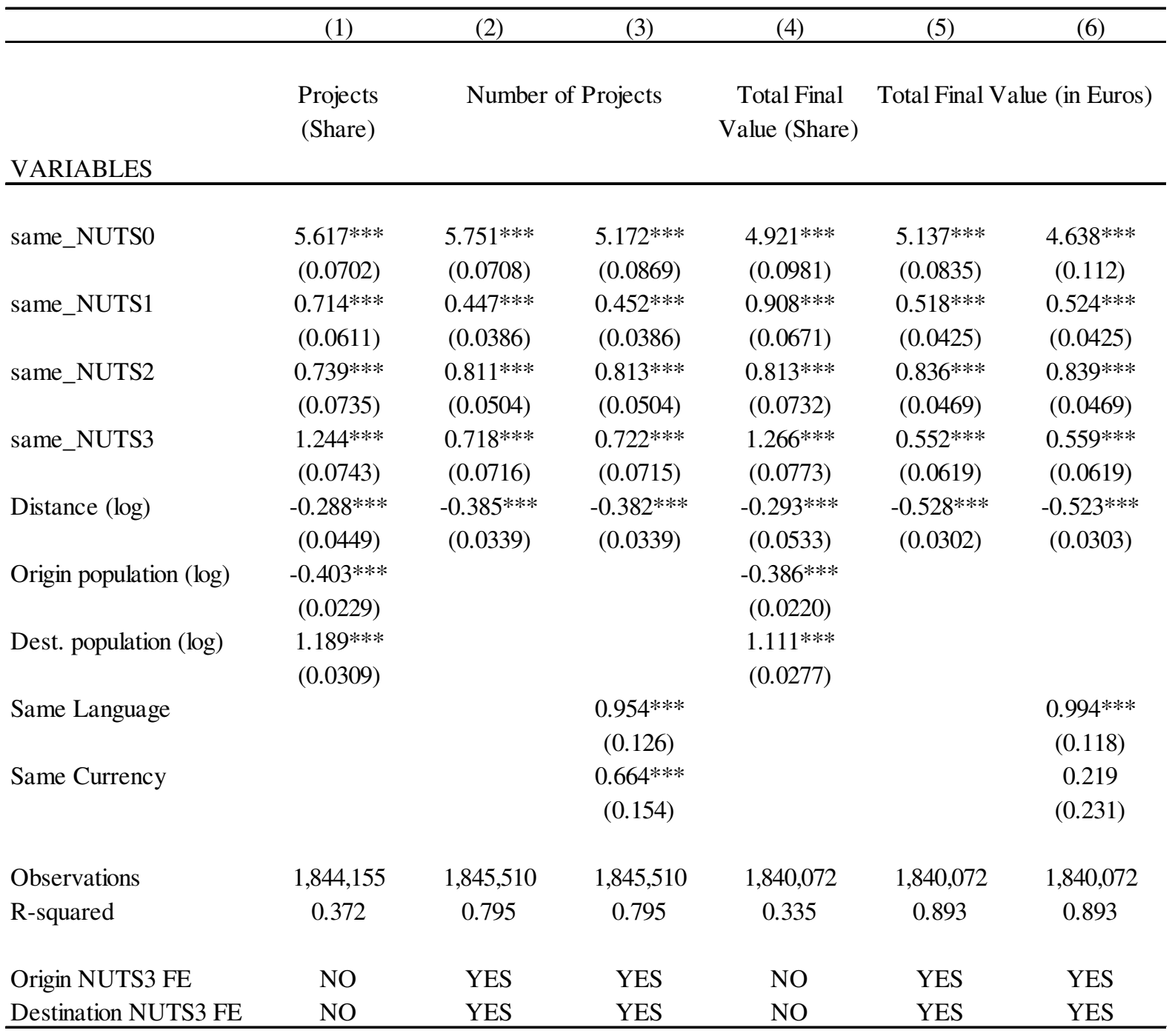

Notes: The tables shows estimates of regression equations (1) and (2). The dependent variable is the number of projects in columns (1) to (3) and the total final value in million Euros in columns (4) to (6). The method of estimation is Poisson pseudo-maximum likelihood (PPML). Columns (1) and (4) include the total projects tendered by authority $i$ as an offset variable. Columns (2), (3), (5), and (6) contain origin- and destination NUTS3 region fixed effects. Eicker-White robust standard errors are shown in parantheses. 
Table 4: Goods, Services, and Construction Works

\begin{tabular}{|c|c|c|c|c|c|c|}
\hline & $(1)$ & $(2)$ & (3) & $(4)$ & $(5)$ & $(6)$ \\
\hline & \multicolumn{3}{|c|}{ Number of Projects } & \multicolumn{3}{|c|}{ Total Final Value in Euros } \\
\hline VARIABLES & Goods & Services & Works & Goods & Services & Works \\
\hline same_NUTS0 & $\begin{array}{c}5.688 * * * \\
(0.0979)\end{array}$ & $\begin{array}{c}4.863 * * * \\
(0.0823)\end{array}$ & $\begin{array}{c}3.677 * * * \\
(0.0843)\end{array}$ & $\begin{array}{c}5.165^{* * *} \\
(0.164)\end{array}$ & $\begin{array}{c}4.979 * * * \\
(0.103)\end{array}$ & $\begin{array}{c}3.817 * * * \\
(0.133)\end{array}$ \\
\hline same_NUTS1 & $\begin{array}{c}0.182^{* * * *} \\
(0.0366)\end{array}$ & $\begin{array}{c}0.721 * * * \\
(0.0406)\end{array}$ & $\begin{array}{c}0.725 * * * \\
(0.0333)\end{array}$ & $\begin{array}{c}0.142 * * * \\
(0.0435)\end{array}$ & $\begin{array}{c}0.615 * * * \\
(0.0479)\end{array}$ & $\begin{array}{c}0.688 * * * \\
(0.0426)\end{array}$ \\
\hline same_NUTS2 & $\begin{array}{c}0.467 * * * \\
(0.0528)\end{array}$ & $\begin{array}{l}1.004 * * * \\
(0.0463)\end{array}$ & $\begin{array}{c}0.725 * * * \\
(0.0381)\end{array}$ & $\begin{array}{c}0.440 * * * \\
(0.0624)\end{array}$ & $\begin{array}{l}1.025 * * * \\
(0.0499)\end{array}$ & $\begin{array}{c}0.754 * * * \\
(0.0445)\end{array}$ \\
\hline same_NUTS3 & $\begin{array}{l}0.206^{* *} \\
(0.0874)\end{array}$ & $\begin{array}{c}0.955^{* * * *} \\
(0.0603)\end{array}$ & $\begin{array}{c}0.797 * * * \\
(0.0502)\end{array}$ & $\begin{array}{l}-0.0460 \\
(0.0725)\end{array}$ & $\begin{array}{c}0.675 * * * \\
(0.0607)\end{array}$ & $\begin{array}{c}0.698 * * * \\
(0.0535)\end{array}$ \\
\hline Distance $(\log )$ & $\begin{array}{c}-0.305 * * * \\
(0.0347)\end{array}$ & $\begin{array}{c}-0.499 * * * \\
(0.0288)\end{array}$ & $\begin{array}{c}-1.071 * * * \\
(0.0207)\end{array}$ & $\begin{array}{c}-0.400 * * * \\
(0.0308)\end{array}$ & $\begin{array}{c}-0.526^{* * *} \\
(0.0316)\end{array}$ & $\begin{array}{c}-1.109 * * * \\
(0.0266)\end{array}$ \\
\hline Same Language & $\begin{array}{c}0.411 * * * \\
(0.145)\end{array}$ & $\begin{array}{c}1.131 * * * \\
(0.143)\end{array}$ & $\begin{array}{c}1.950 * * * \\
(0.150)\end{array}$ & $\begin{array}{c}0.382 * * * \\
(0.129)\end{array}$ & $\begin{array}{c}0.888 * * * \\
(0.157)\end{array}$ & $\begin{array}{c}1.924 * * * \\
(0.216)\end{array}$ \\
\hline Same Currency & $\begin{array}{c}0.796 * * * \\
(0.185)\end{array}$ & $\begin{array}{c}0.355^{*} \\
(0.201)\end{array}$ & $\begin{array}{l}0.0950 \\
(0.190)\end{array}$ & $\begin{array}{c}0.117 \\
(0.299)\end{array}$ & $\begin{array}{c}0.353 * \\
(0.188)\end{array}$ & $\begin{array}{l}0.720 * * \\
(0.338)\end{array}$ \\
\hline Observations & $1,811,680$ & $1,837,360$ & $1,703,778$ & $1,760,733$ & $1,804,936$ & $1,335,642$ \\
\hline R-squared & 0.872 & 0.881 & 0.928 & 0.917 & 0.941 & 0.926 \\
\hline Origin NUTS3 FE & YES & YES & YES & YES & YES & YES \\
\hline Destination NUTS3 FE & YES & YES & YES & YES & YES & YES \\
\hline
\end{tabular}

Notes: The tables shows estimates of regression equations (2). The dependent variable is the number of projects involving goods, no goods, services, and construction in columns (1) to (3). In columns (4) to (6) the dependent variable is the total final value in million Euros. The method of estimation is Poisson pseudo-maximum likelihood (PPML). All specification includes origin and destination NUTS3 region fixed effects. Eicker-White robust standard errors are shown in parantheses. 


\section{Table 5: Award Criteria}

Panel A: Only Projects using the "Most economically advantageous tender" award criterion

\begin{tabular}{|c|c|c|c|c|c|c|c|c|}
\hline \multirow[b]{3}{*}{ VARIABLES } & (1) & (2) & (3) & (4) & (5) & (6) & (7) & (8) \\
\hline & \multicolumn{4}{|c|}{ Number of Projects } & \multicolumn{4}{|c|}{ Total Final Value in Euros } \\
\hline & All & Goods & Services & Works & All & Goods & Services & Works \\
\hline same_NUTS0 & $\begin{array}{c}4.365 * * * \\
(0.0636)\end{array}$ & $\begin{array}{l}4.696 * * * \\
(0.0735)\end{array}$ & $\begin{array}{l}4.453 * * * \\
(0.0892)\end{array}$ & $\begin{array}{c}3.328 * * * \\
(0.101)\end{array}$ & $\begin{array}{c}4.159 * * * \\
(0.0738)\end{array}$ & $\begin{array}{l}4.510 * * * \\
(0.0925)\end{array}$ & $\begin{array}{c}4.472 * * * \\
(0.112)\end{array}$ & $\begin{array}{c}3.354 * * * \\
(0.192)\end{array}$ \\
\hline same_NUTS1 & $\begin{array}{c}0.567 * * * \\
(0.0324)\end{array}$ & $\begin{array}{c}0.333 * * * \\
(0.0337)\end{array}$ & $\begin{array}{c}0.718^{* * * *} \\
(0.0389)\end{array}$ & $\begin{array}{c}0.671 * * * \\
(0.0409)\end{array}$ & $\begin{array}{c}0.523 * * * * \\
(0.0414)\end{array}$ & $\begin{array}{c}0.149 * * * \\
(0.0416)\end{array}$ & $\begin{array}{c}0.599 * * * \\
(0.0485)\end{array}$ & $\begin{array}{c}0.625^{* * * *} \\
(0.0544)\end{array}$ \\
\hline same_NUTS2 & $\begin{array}{c}0.778 * * * \\
(0.0455)\end{array}$ & $\begin{array}{c}0.412 * * * \\
(0.0449)\end{array}$ & $\begin{array}{c}0.938 * * * \\
(0.0513)\end{array}$ & $\begin{array}{c}0.950 * * * \\
(0.0491)\end{array}$ & $\begin{array}{c}0.944 * * * \\
(0.0449)\end{array}$ & $\begin{array}{c}0.322 * * * \\
(0.0470)\end{array}$ & $\begin{array}{c}1.154 * * * \\
(0.0528)\end{array}$ & $\begin{array}{l}1.009^{* * * *} \\
(0.0617)\end{array}$ \\
\hline same_NUTS3 & $\begin{array}{c}0.900 * * * \\
(0.0648)\end{array}$ & $\begin{array}{c}0.584 * * * \\
(0.0745)\end{array}$ & $\begin{array}{l}0.888 \text { **** } \\
(0.0692)\end{array}$ & $\begin{array}{c}0.945 * * * \\
(0.0554)\end{array}$ & $\begin{array}{c}0.728 * * * \\
(0.0628)\end{array}$ & $\begin{array}{c}0.218 * * * \\
(0.0794)\end{array}$ & $\begin{array}{c}0.609 * * * \\
(0.0621)\end{array}$ & $\begin{array}{c}0.893 * * * \\
(0.0639)\end{array}$ \\
\hline Distance $(\log )$ & $\begin{array}{c}-0.516^{* * * *} \\
(0.0229)\end{array}$ & $\begin{array}{r}-0.450^{* * * *} \\
(0.0225)\end{array}$ & $\begin{array}{c}-0.536 * * * \\
(0.0285)\end{array}$ & $\begin{array}{r}-1.063^{* * * *} \\
(0.0269)\end{array}$ & $\begin{array}{r}-0.608 * * * * \\
(0.0246)\end{array}$ & $\begin{array}{r}-0.533 * * * \\
(0.0247)\end{array}$ & $\begin{array}{r}-0.604 * * * * \\
(0.0299)\end{array}$ & $\begin{array}{r}-1.108^{* * * *} \\
(0.0389)\end{array}$ \\
\hline Same Language & $\begin{array}{c}1.231 * * * \\
(0.0874)\end{array}$ & $\begin{array}{c}0.852 * * * \\
(0.0881)\end{array}$ & $\begin{array}{c}1.371 * * * \\
(0.133)\end{array}$ & $\begin{array}{c}2.047 * * * \\
(0.176)\end{array}$ & $\begin{array}{c}0.955 * * * \\
(0.0968)\end{array}$ & $\begin{array}{c}0.548 * * * \\
(0.120)\end{array}$ & $\begin{array}{c}0.985 * * * \\
(0.180)\end{array}$ & $\begin{array}{c}1.983 * * * \\
(0.344)\end{array}$ \\
\hline Same Currency & $\begin{array}{c}0.731 * * * \\
(0.136)\end{array}$ & $\begin{array}{c}0.897 * * * \\
(0.147)\end{array}$ & $\begin{array}{c}0.463^{* *} \\
(0.218)\end{array}$ & $\begin{array}{c}0.141 \\
(0.242)\end{array}$ & $\begin{array}{c}0.850^{* * * *} \\
(0.130)\end{array}$ & $\begin{array}{c}0.626 * * * \\
(0.153)\end{array}$ & $\begin{array}{c}1.178^{* * * *} \\
(0.225)\end{array}$ & $\begin{array}{c}0.717 \\
(0.564)\end{array}$ \\
\hline Observations & $1,800,939$ & $1,699,112$ & $1,772,850$ & $1,414,320$ & $1,779,492$ & $1,623,012$ & $1,706,810$ & 870,420 \\
\hline R-squared & 0.844 & 0.871 & 0.844 & 0.957 & 0.889 & 0.874 & 0.928 & 0.960 \\
\hline Origin NUTS3 FE & YES & YES & YES & YES & YES & YES & YES & YES \\
\hline Destination NUTS3 FE & YES & YES & YES & YES & YES & YES & YES & YES \\
\hline
\end{tabular}

Panel B: Only Projects using the "Lowest Price" award criterion

\begin{tabular}{|c|c|c|c|c|c|c|c|c|}
\hline & (1) & (2) & (3) & $(4)$ & (5) & (6) & (7) & (8) \\
\hline & \multicolumn{4}{|c|}{ Number of Projects } & \multicolumn{4}{|c|}{ Total Final Value in Euros } \\
\hline VARIABLES & All & Goods & Services & Works & All & Goods & Services & Works \\
\hline same_NUTS0 & $\begin{array}{c}5.898 * * * \\
(0.128)\end{array}$ & $\begin{array}{c}6.241 * * * \\
(0.137)\end{array}$ & $\begin{array}{c}5.381 * * * \\
(0.131)\end{array}$ & $\begin{array}{c}4.111 * * * \\
(0.125)\end{array}$ & $\begin{array}{c}5.177 * * * \\
(0.222)\end{array}$ & $\begin{array}{c}5.603 * * * \\
(0.293)\end{array}$ & $\begin{array}{c}5.554 * * * \\
(0.165)\end{array}$ & $\begin{array}{c}4.383 * * * \\
(0.225)\end{array}$ \\
\hline same_NUTS1 & $\begin{array}{c}0.231 * * * \\
(0.0549)\end{array}$ & $\begin{array}{c}0.0401 \\
(0.0486)\end{array}$ & $\begin{array}{c}0.740 * * * \\
(0.0674)\end{array}$ & $\begin{array}{c}0.513 * * * \\
(0.0366)\end{array}$ & $\begin{array}{c}0.343 * * * \\
(0.0539)\end{array}$ & $\begin{array}{c}0.0728 \\
(0.0631)\end{array}$ & $\begin{array}{c}0.582 * * * \\
(0.0670)\end{array}$ & $\begin{array}{c}0.487 * * * * \\
(0.0519)\end{array}$ \\
\hline same_NUTS2 & $\begin{array}{c}0.818 * * * \\
(0.0731)\end{array}$ & $\begin{array}{c}0.444 * * * \\
(0.0711)\end{array}$ & $\begin{array}{l}1.126 * * * \\
(0.0725)\end{array}$ & $\begin{array}{c}0.405 * * * \\
(0.0340)\end{array}$ & $\begin{array}{c}0.692 * * * * \\
(0.0633)\end{array}$ & $\begin{array}{c}0.498 * * * \\
(0.106)\end{array}$ & $\begin{array}{c}0.835 * * * \\
(0.0662)\end{array}$ & $\begin{array}{c}0.445 * * * \\
(0.0482)\end{array}$ \\
\hline same_NUTS3 & $\begin{array}{c}0.382^{* * * *} \\
(0.114)\end{array}$ & $\begin{array}{c}-0.0673 \\
(0.105)\end{array}$ & $\begin{array}{l}1.004 * * * \\
(0.0884)\end{array}$ & $\begin{array}{l}-0.0481 \\
(0.0448)\end{array}$ & $\begin{array}{c}0.151^{*} \\
(0.0813)\end{array}$ & $\begin{array}{c}-0.211^{* *} \\
(0.100)\end{array}$ & $\begin{array}{c}0.790 * * * \\
(0.0936)\end{array}$ & $\begin{array}{c}-0.164 * * * \\
(0.0585)\end{array}$ \\
\hline Distance $(\log )$ & $\begin{array}{c}-0.274 * * * \\
(0.0542)\end{array}$ & $\begin{array}{c}-0.239 * * * \\
(0.0490)\end{array}$ & $\begin{array}{c}-0.438 * * * \\
(0.0519)\end{array}$ & $\begin{array}{c}-1.203 * * * \\
(0.0206)\end{array}$ & $\begin{array}{c}-0.510 * * * \\
(0.0429)\end{array}$ & $\begin{array}{c}-0.317 * * * \\
(0.0502)\end{array}$ & $\begin{array}{c}-0.446 * * * \\
(0.0496)\end{array}$ & $\begin{array}{c}-1.240 * * * \\
(0.0275)\end{array}$ \\
\hline Same Language & $\begin{array}{c}0.967 * * * \\
(0.227)\end{array}$ & $\begin{array}{c}0.337 \\
(0.249)\end{array}$ & $\begin{array}{c}1.235 * * * \\
(0.217)\end{array}$ & $\begin{array}{c}1.889 * * * \\
(0.238)\end{array}$ & $\begin{array}{c}0.897 * * * * \\
(0.197)\end{array}$ & $\begin{array}{c}0.307 \\
(0.242)\end{array}$ & $\begin{array}{c}0.949 * * * \\
(0.261)\end{array}$ & $\begin{array}{c}1.475 * * * \\
(0.346)\end{array}$ \\
\hline Same Currency & $\begin{array}{c}0.205 \\
(0.279)\end{array}$ & $\begin{array}{c}0.276 \\
(0.311)\end{array}$ & $\begin{array}{c}-0.0253 \\
(0.309)\end{array}$ & $\begin{array}{l}0.0785 \\
(0.278)\end{array}$ & $\begin{array}{l}-0.341 \\
(0.359)\end{array}$ & $\begin{array}{l}-0.358 \\
(0.441)\end{array}$ & $\begin{array}{l}-0.403 \\
(0.261)\end{array}$ & $\begin{array}{l}0.940 * \\
(0.498)\end{array}$ \\
\hline Observations & $1,796,700$ & $1,507,124$ & $1,711,360$ & $1,340,696$ & $1,687,368$ & $1,276,740$ & $1,510,110$ & 909,084 \\
\hline R-squared & 0.851 & 0.936 & 0.879 & 0.870 & 0.923 & 0.941 & 0.939 & 0.869 \\
\hline Origin NUTS3 FE & YES & YES & YES & YES & YES & YES & YES & YES \\
\hline Destination NUTS3 FE & YES & YES & YES & YES & YES & YES & YES & YES \\
\hline $\begin{array}{l}\text { Notes: The tables sho } \\
\text { advantageous tender" ( } \\
\text { number of projects, the } \\
\text { dependent variable is th } \\
\text { (PPML). All specificati } \\
\text { shown in parantheses. }\end{array}$ & estimate & cot pice & . & (2). 11t & . & III. & 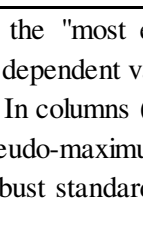 & to $(8)$ \\
\hline
\end{tabular}


Table 6: Open Procedure

\begin{tabular}{|c|c|c|c|c|c|c|c|c|}
\hline & (1) & (2) & (3) & (4) & (5) & (6) & (7) & $(8)$ \\
\hline & \multicolumn{4}{|c|}{ Number of Projects } & \multicolumn{4}{|c|}{ Total Final Value in Euros } \\
\hline VARIABLES & All & Goods & Services & Works & All & Goods & Services & Works \\
\hline same_NUTS0 & $\begin{array}{l}5.285^{* * *} \\
(0.0927)\end{array}$ & $\begin{array}{c}5.815^{* * *} \\
(0.106)\end{array}$ & $\begin{array}{l}4.937 * * * \\
(0.0869)\end{array}$ & $\begin{array}{l}3.703 * * * \\
(0.0905)\end{array}$ & $\begin{array}{c}4.750 * * * \\
(0.162)\end{array}$ & $\begin{array}{c}5.300^{* * *} \\
(0.219)\end{array}$ & $\begin{array}{c}5.132 * * * \\
(0.119)\end{array}$ & $\begin{array}{c}3.953 * * * \\
(0.149)\end{array}$ \\
\hline same_NUTS1 & $\begin{array}{c}0.424 * * * \\
(0.0401)\end{array}$ & $\begin{array}{c}0.180 * * * \\
(0.0376)\end{array}$ & $\begin{array}{c}0.707 * * * \\
(0.0419)\end{array}$ & $\begin{array}{c}0.708^{* * * *} \\
(0.0322)\end{array}$ & $\begin{array}{c}0.516^{* * * *} \\
(0.0431)\end{array}$ & $\begin{array}{c}0.156^{* * * *} \\
(0.0462)\end{array}$ & $\begin{array}{l}0.602 * * * \\
(0.0486)\end{array}$ & $\begin{array}{c}0.691 * * * \\
(0.0424)\end{array}$ \\
\hline same_NUTS2 & $\begin{array}{l}0.801 * * * \\
(0.0518)\end{array}$ & $\begin{array}{c}0.480 * * * \\
(0.0545)\end{array}$ & $\begin{array}{l}1.020 * * * \\
(0.0456)\end{array}$ & $\begin{array}{c}0.713 * * * \\
(0.0368)\end{array}$ & $\begin{array}{c}0.838 * * * \\
(0.0474)\end{array}$ & $\begin{array}{c}0.471 * * * \\
(0.0685)\end{array}$ & $\begin{array}{l}1.055 * * * \\
(0.0504)\end{array}$ & $\begin{array}{c}0.742 * * * \\
(0.0448)\end{array}$ \\
\hline same_NUTS3 & $\begin{array}{l}0.713 * * * \\
(0.0733)\end{array}$ & $\begin{array}{c}0.196^{* *} \\
(0.0898)\end{array}$ & $\begin{array}{c}0.949 * * * \\
(0.0573)\end{array}$ & $\begin{array}{c}0.714 * * * \\
(0.0492)\end{array}$ & $\begin{array}{l}0.576 * * * \\
(0.0614)\end{array}$ & $\begin{array}{l}-0.0375 \\
(0.0752)\end{array}$ & $\begin{array}{l}0.696 * * * \\
(0.0596)\end{array}$ & $\begin{array}{c}0.665^{* * *} \\
(0.0530)\end{array}$ \\
\hline Distance $(\log )$ & $\begin{array}{c}-0.395 * * * \\
(0.0364)\end{array}$ & $\begin{array}{c}-0.301 * * * \\
(0.0362)\end{array}$ & $\begin{array}{c}-0.558^{* * * *} \\
(0.0290)\end{array}$ & $\begin{array}{c}-1.105^{* * * *} \\
(0.0203)\end{array}$ & $\begin{array}{c}-0.548^{* * *} \\
(0.0315)\end{array}$ & $\begin{array}{c}-0.391 * * * \\
(0.0337)\end{array}$ & $\begin{array}{c}-0.568 * * * \\
(0.0328)\end{array}$ & $\begin{array}{r}-1.133^{* * * *} \\
(0.0266)\end{array}$ \\
\hline Same Language & $\begin{array}{c}1.128 * * * \\
(0.140)\end{array}$ & $\begin{array}{c}0.676 \text { *** } \\
(0.170)\end{array}$ & $\begin{array}{c}1.136 * * * \\
(0.143)\end{array}$ & $\begin{array}{c}2.177 * * * \\
(0.178)\end{array}$ & $\begin{array}{c}1.218 * * * \\
(0.121)\end{array}$ & $\begin{array}{c}0.694 * * * \\
(0.145)\end{array}$ & $\begin{array}{c}0.943 * * * \\
(0.186)\end{array}$ & $\begin{array}{c}1.979 * * * \\
(0.236)\end{array}$ \\
\hline Same Currency & $\begin{array}{c}0.676^{* * * *} \\
(0.184)\end{array}$ & $\begin{array}{c}0.737 * * * \\
(0.223)\end{array}$ & $\begin{array}{c}0.515^{* * * *} \\
(0.198)\end{array}$ & $\begin{array}{c}-0.0394 \\
(0.212)\end{array}$ & $\begin{array}{c}0.166 \\
(0.297)\end{array}$ & $\begin{array}{l}0.0372 \\
(0.370)\end{array}$ & $\begin{array}{c}0.444 * * \\
(0.212)\end{array}$ & $\begin{array}{c}0.521 \\
(0.364)\end{array}$ \\
\hline Observations & $1,844,148$ & $1,808,976$ & $1,830,560$ & $1,688,148$ & $1,840,072$ & $1,754,090$ & $1,783,428$ & $1,273,536$ \\
\hline R-squared & 0.773 & 0.871 & 0.872 & 0.931 & 0.870 & 0.910 & 0.929 & 0.929 \\
\hline Origin NUTS3 FE & YES & YES & YES & YES & YES & YES & YES & YES \\
\hline Destination NUTS3 FE & YES & YES & YES & YES & YES & YES & YES & YES \\
\hline
\end{tabular}

Notes: The tables shows estimates of regression equations (2) using the subsample of projects published under the open procedure. The dependent variable is the number of projects, the projects involving goods, services, and construction works in columns (1) to (4). In columns (5) to (8) the dependent variable is the total final value in million Euros. The method of estimation is Poisson pseudo-maximum likelihood (PPML). All specification includes origin and destination NUTS3 region fixed effects. Eicker-White robust standard errors are shown in parantheses. 
Table 7: Cultural Distance

\begin{tabular}{|c|c|c|c|c|c|c|c|c|}
\hline & $(1)$ & $(2)$ & (3) & (4) & $(5)$ & $(6)$ & $(7)$ & $(8)$ \\
\hline & \multicolumn{4}{|c|}{ Number of Projects } & \multicolumn{4}{|c|}{ Total Final Value in Euros } \\
\hline VARIABLES & All & Goods & Services & Works & All & Goods & Services & Works \\
\hline same_NUTS0 & $\begin{array}{c}4.846 * * * \\
(0.135)\end{array}$ & $\begin{array}{c}5.185^{* * * *} \\
(0.190)\end{array}$ & $\begin{array}{c}4.682 * * * \\
(0.155)\end{array}$ & $\begin{array}{c}3.692 * * * \\
(0.117)\end{array}$ & $\begin{array}{c}4.792 * * * \\
(0.286)\end{array}$ & $\begin{array}{c}5.275 * * * \\
(0.436)\end{array}$ & $\begin{array}{c}4.900 * * * \\
(0.152)\end{array}$ & $\begin{array}{c}4.116^{* * * *} \\
(0.210)\end{array}$ \\
\hline same_NUTS1 & $\begin{array}{c}0.452 * * * \\
(0.0386)\end{array}$ & $\begin{array}{c}0.182 * * * \\
(0.0366)\end{array}$ & $\begin{array}{c}0.721 * * * \\
(0.0406)\end{array}$ & $\begin{array}{c}0.725 * * * \\
(0.0334)\end{array}$ & $\begin{array}{c}0.524 * * * \\
(0.0426)\end{array}$ & $\begin{array}{l}0.141 * * * \\
(0.0434)\end{array}$ & $\begin{array}{l}0.615 * * * \\
(0.0479)\end{array}$ & $\begin{array}{c}0.688 * * * \\
(0.0426)\end{array}$ \\
\hline same_NUTS2 & $\begin{array}{c}0.816 * * * \\
(0.0504)\end{array}$ & $\begin{array}{c}0.471 * * * \\
(0.0529)\end{array}$ & $\begin{array}{l}1.005 * * * \\
(0.0463)\end{array}$ & $\begin{array}{c}0.726 * * * \\
(0.0381)\end{array}$ & $\begin{array}{c}0.841 * * * \\
(0.0470)\end{array}$ & $\begin{array}{c}0.445 * * * \\
(0.0636)\end{array}$ & $\begin{array}{l}1.026 * * * \\
(0.0499)\end{array}$ & $\begin{array}{c}0.755^{* * * *} \\
(0.0445)\end{array}$ \\
\hline same_NUTS3 & $\begin{array}{c}0.724 * * * \\
(0.0715)\end{array}$ & $\begin{array}{l}0.209 * * \\
(0.0874)\end{array}$ & $\begin{array}{c}0.956 * * * \\
(0.0603)\end{array}$ & $\begin{array}{c}0.798 * * * \\
(0.0502)\end{array}$ & $\begin{array}{c}0.559 * * * \\
(0.0619)\end{array}$ & $\begin{array}{l}-0.0429 \\
(0.0726)\end{array}$ & $\begin{array}{c}0.675 * * * \\
(0.0607)\end{array}$ & $\begin{array}{c}0.698 * * * \\
(0.0535)\end{array}$ \\
\hline Distance (log) & $\begin{array}{c}-0.380 * * * \\
(0.0339)\end{array}$ & $\begin{array}{c}-0.301 * * * \\
(0.0347)\end{array}$ & $\begin{array}{c}-0.498 * * * \\
(0.0288)\end{array}$ & $\begin{array}{c}-1.071 * * * \\
(0.0207)\end{array}$ & $\begin{array}{c}-0.522 * * * * \\
(0.0304)\end{array}$ & $\begin{array}{c}-0.398 * * * \\
(0.0312)\end{array}$ & $\begin{array}{c}-0.525 * * * \\
(0.0316)\end{array}$ & $\begin{array}{c}-1.109 * * * * \\
(0.0266)\end{array}$ \\
\hline Trust & $\begin{array}{c}-2.169 * * * \\
(0.364)\end{array}$ & $\begin{array}{c}-2.238 * * * \\
(0.442)\end{array}$ & $\begin{array}{c}-1.287 * * * \\
(0.439)\end{array}$ & $\begin{array}{c}-1.579 * * * \\
(0.515)\end{array}$ & $\begin{array}{c}-1.792 * * * * \\
(0.580)\end{array}$ & $\begin{array}{c}-1.833 * * * \\
(0.704)\end{array}$ & $\begin{array}{c}-0.755^{*} \\
(0.429)\end{array}$ & $\begin{array}{c}-2.881 * * * * \\
(0.801)\end{array}$ \\
\hline Hierarchy & $\begin{array}{l}0.0386 \\
(0.875)\end{array}$ & $\begin{array}{l}-0.273 \\
(1.035)\end{array}$ & $\begin{array}{l}-1.378 \\
(1.169)\end{array}$ & $\begin{array}{c}0.636 \\
(0.828)\end{array}$ & $\begin{array}{c}0.655 \\
(1.393)\end{array}$ & $\begin{array}{c}0.642 \\
(1.797)\end{array}$ & $\begin{array}{c}-2.195^{* *} \\
(0.862)\end{array}$ & $\begin{array}{c}3.285^{* *} \\
(1.392)\end{array}$ \\
\hline Individualism & $\begin{array}{c}-0.807 \\
(1.016)\end{array}$ & $\begin{array}{c}-2.053 \\
(1.319)\end{array}$ & $\begin{array}{c}0.808 \\
(0.991)\end{array}$ & $\begin{array}{c}1.170 \\
(0.739)\end{array}$ & $\begin{array}{c}2.431 * * \\
(1.198)\end{array}$ & $\begin{array}{c}1.789 \\
(1.489)\end{array}$ & $\begin{array}{l}1.806^{* *} \\
(0.770)\end{array}$ & $\begin{array}{c}2.982 * * * \\
(1.066)\end{array}$ \\
\hline Same Language & $\begin{array}{c}0.930 * * * \\
(0.102)\end{array}$ & $\begin{array}{c}0.446 * * * \\
(0.110)\end{array}$ & $\begin{array}{c}1.119 * * * \\
(0.129)\end{array}$ & $\begin{array}{c}1.907 * * * \\
(0.169)\end{array}$ & $\begin{array}{c}0.966 * * * \\
(0.108)\end{array}$ & $\begin{array}{l}0.311^{* *} \\
(0.127)\end{array}$ & $\begin{array}{c}0.939 * * * \\
(0.156)\end{array}$ & $\begin{array}{c}1.873 * * * \\
(0.228)\end{array}$ \\
\hline Same Currency & $\begin{array}{c}0.734 * * * \\
(0.169)\end{array}$ & $\begin{array}{c}0.906^{* * *} \\
(0.212)\end{array}$ & $\begin{array}{l}0.369^{*} \\
(0.208)\end{array}$ & $\begin{array}{l}0.0389 \\
(0.194)\end{array}$ & $\begin{array}{c}0.156 \\
(0.259)\end{array}$ & $\begin{array}{l}0.0499 \\
(0.343)\end{array}$ & $\begin{array}{l}0.342 * \\
(0.191)\end{array}$ & $\begin{array}{l}0.633^{*} \\
(0.333)\end{array}$ \\
\hline Observations & $1,842,794$ & $1,808,989$ & $1,834,650$ & $1,701,168$ & $1,837,360$ & $1,758,080$ & $1,802,250$ & $1,333,326$ \\
\hline R-squared & 0.795 & 0.872 & 0.881 & 0.928 & 0.893 & 0.917 & 0.941 & 0.926 \\
\hline Origin NUTS3 FE & YES & YES & YES & YES & YES & YES & YES & YES \\
\hline Destination NUTS3 FE & YES & YES & YES & YES & YES & YES & YES & YES \\
\hline
\end{tabular}

Notes: The tables shows estimates of and extended regression equation (2) that, following Ahern et al. (2015), includes three measures that capture national attitudes regarding (i) trust versus distrust, (ii) hierarchy versus egalitarianism, and (iii) individualism versus collectivism. The dependent variable is the number of projects, the projects involving goods, services, and construction works in columns (1) to (4). In columns (5) to (8) the dependent variable is the total final value in million Euros. The method of estimation is Poisson pseudo-maximum likelihood (PPML). All specification includes origin and destination NUTS3 region fixed effects. Eicker-White robust standard errors are shown in parantheses. 
Figure 1: Share of cross-border by NUTS3 region

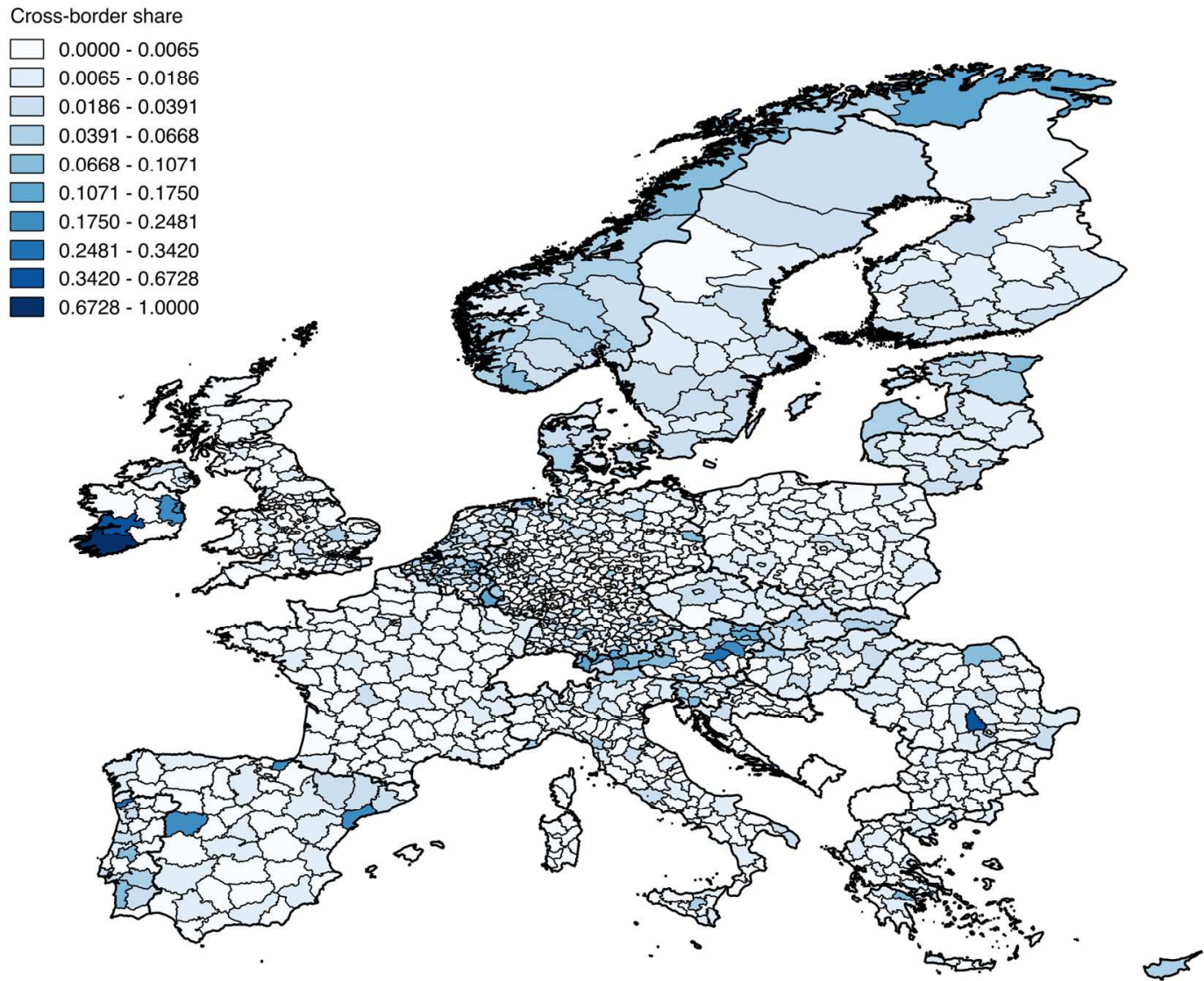

Notes: The figure shows the share of cross-border (NUTS0) procurement share by origin NUTS3 region. 
Figure 2: Example of the geographic distribution of awards

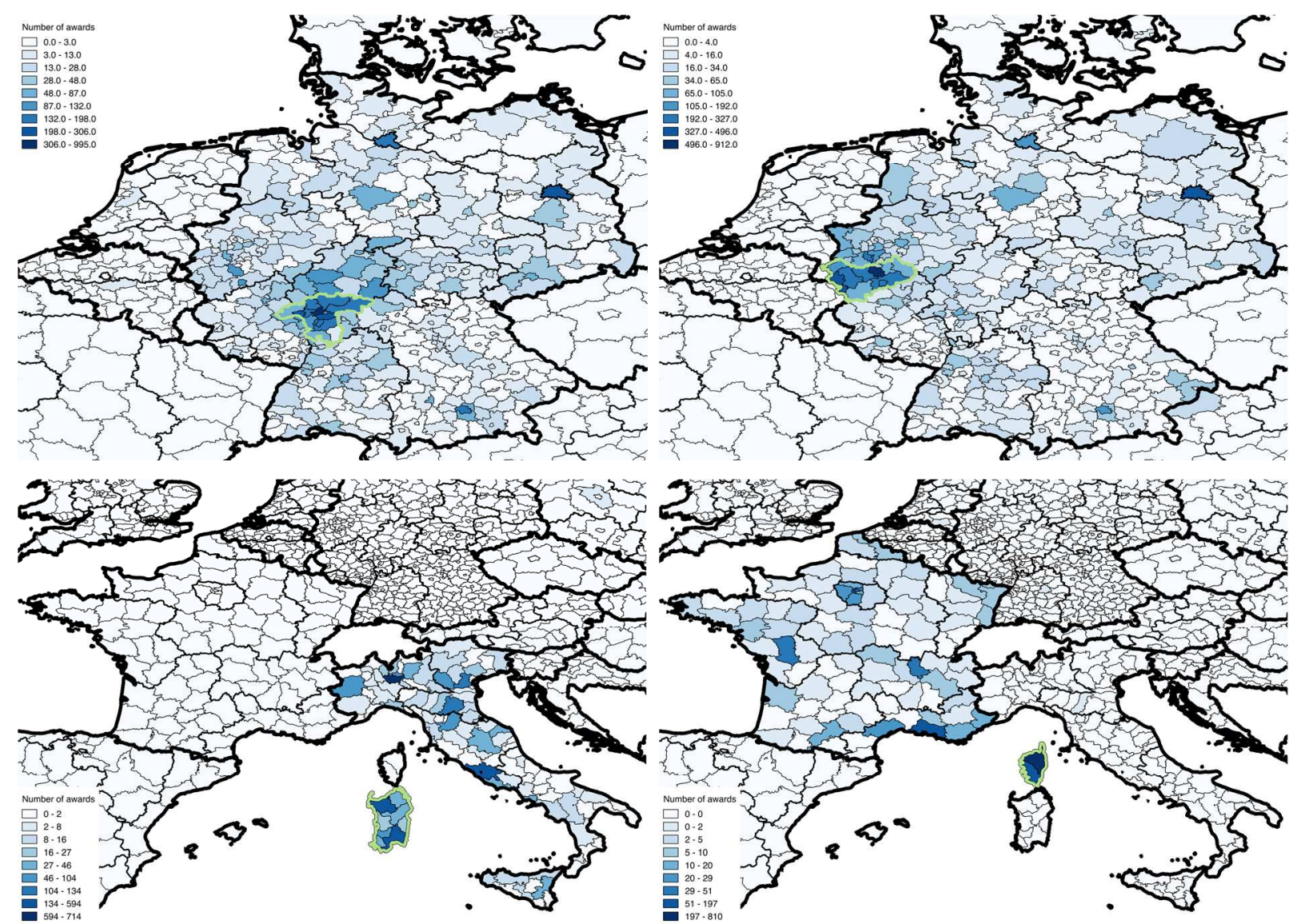

Notes: Clockwise from the top left, the figure shows the geographic distribution of contract awards by contracting authorities or entities (CAE) located in NUTS2 regions Cologne (DEA2), Darmstadt/Frankfurt am Main (DE71), Corsica (FR83), and Sardinia (ITG2). 